\title{
Entrepreneurs' age, institutions, and social value creation goals: A multi-country study
}

\author{
Steven A. Brieger (D) - Anne Bäro • Giuseppe Criaco • \\ Siri A. Terjesen
}

Accepted: 9 January 2020 / Published online: 24 January 2020

(C) The Author(s) 2020

\begin{abstract}
This study explores the relationship between an entrepreneur's age and his/her social value creation goals. Building on the lifespan developmental psychology literature and institutional theory, we hypothesize a U-shaped relationship between entrepreneurs' age and their choice to create social value through their ventures, such that younger and older entrepreneurs create more social value with their businesses while middle age entrepreneurs are relatively more economically and less socially oriented with their ventures. We further hypothesize that the quality of a country's formal institutions in terms of economic, social, and political freedom steepen the U-shaped relationship between entrepreneurs' age
\end{abstract}

S. A. Brieger $(\bowtie)$

University of Sussex Business School, University of Sussex, Brighton, UK

e-mail: s.a.brieger@sussex.ac.uk

A. Bäro

Dr. Arend Oetker Chair of Business Psychology and Leadership, HHL Leipzig Graduate School of Management, Leipzig, Germany e-mail: anne.baero@hhl.de

\section{G. Criaco}

Rotterdam School of Management, Erasmus University,

Rotterdam, The Netherlands

e-mail: criaco@rsm.nl

\section{S. A. Terjesen}

College of Business, Florida Atlantic University, Florida, USA

e-mail: sterjesen@fau.edu

\section{S. A. Terjesen}

Norwegian School of Economics, Bergen, Norway and their choice to pursue social value creation as supportive institutional environments allow entrepreneurs to follow their age-based preferences. We confirm our predictions using multilevel mixed-effects linear regressions on a sample of over 15,000 entrepreneurs (aged between 18 and 64 years) in 45 countries from Global Entrepreneurship Monitor data. The findings are robust to several alternative specifications. Based on our findings, we discuss implications for theory and practice, and we propose future research directions.

Keywords Age · Lifespan psychology · Social value · Social entrepreneurship · Entrepreneurship · Formal institutions

JEL classifications $\mathrm{L} 26 \cdot \mathrm{L} 31 \cdot \mathrm{Q} 01 \cdot \mathrm{P} 48 \cdot \mathrm{M} 14 \cdot \mathrm{M} 16$

\section{Introduction}

Individuals' orientation towards entrepreneurial activities differs depending on where they stand in their lifespans (Gielnik et al. 2012; Kautonen et al. 2017; Lévesque and Minniti 2006; Parker 2009). Prior research provides strong empirical support for an inverted U-shaped relationship between individuals' age and their entrepreneurial motivations, intentions, and behaviors, showing that middle-aged individuals are typically more likely to engage, or show an interest, in entrepreneurship (Bönte et al. 2009; Curran and Blackburn 
2001; Funken and Gielnik 2015; Lévesque and Minniti 2006; Minola et al. 2016; Parker 2009).

Although existing research offers important insights on the relationship between individuals' age and their entrepreneurial behavior, we know little about which types of goals (i.e. social, economic, or environmental) entrepreneurs pursue in different life stages through their organizations. This knowledge gap is surprising given that previous research in the social sciences identifies significant age differences in people's attitudes, values, intentions, and behaviors. For instance, lifespan developmental psychology argues that people's goals and motives differ depending on their lifespan stage (Baltes et al. 2006; Ebner et al. 2006). This perspective suggests that while younger people look for value recognition, social acceptance, and social embeddedness, people in middle adulthood instead prioritize growth and maintenance, and older adults typically show higher levels of conscientiousness (Carstensen 2006; Lang and Carstensen 2002; Roberts et al. 2006). Political science research presents evidence for enduring birth cohort effects by showing that younger people give more priority to postmaterialist values (selfexpression and quality of life) than materialistic values (economic and physical security) compared with their older counterparts (Inglehart 1997; Inglehart and Welzel 2005). People shift their values from materialist to postmaterialist once they experience conditions free of economic and physical insecurities. As, on average, younger cohorts grew up in safer and more prosperous conditions than their older counterparts, young people are more postmaterialist which is linked with a rising sense for human autonomy, tolerance, trust, and equality (Inglehart 1997; Inglehart and Welzel 2005).

In this study, we explore the relationship between entrepreneurs' age and their social value creation goals by examining cross-sectional age differences in entrepreneurs' choice to create social value through their ventures. ${ }^{1}$ Social value creation is "defined broadly as that which enhances well-being for the earth and its living organism" (Brickson 2007, p. 866). Entrepreneurs who follow social value creation

\footnotetext{
${ }^{1}$ Notably, the focus of this study is not on social entrepreneurs or the creation of social enterprises, but rather on how any entrepreneur might create social value, in addition to economic or other forms of value creation, in his/her business endeavors, depending on his/her age.
}

goals seek to improve society by contributing towards basic needs fulfillment and well-being, positive health, and a healthy environment (De Ruysscher et al. 2017). Drawing on lifespan developmental psychology (Baltes et al. 2006; Ebner et al. 2006), we argue that entrepreneurs' priorities for social (versus economic) objectives differ over the stages of their lifetimes. More precisely, we hypothesize a U-shaped relationship between an entrepreneur's age and his/her willingness to create social value. We propose that the focus on social value creation decreases with increasing age throughout early middle adulthood, during which entrepreneurs are more likely to prioritize personal welfare and economic motives over social motives, and later increases again during late middle adulthood. Accordingly, compared with middle-aged entrepreneurs, younger and older entrepreneurs are more likely to prioritize social goals, which contribute to the wealth of their communities and societies. Moreover, we look at the role that formal institutions play in modifying this relationship since institutions are believed to regulate individuals' behavior through binding political, economic, and contractual rules (North 1990). We argue that a country's institutional quality moderates the curvilinear relationship between entrepreneurs' age and social value creation, such that better institutional quality steepens the Ushaped relationship between entrepreneurs' age and their choice to pursue social value creation through their organizations; this is because supportive, welldesigned institutional environments help entrepreneurs to follow their preferences.

We find support for our predictions in a sample of more than 15,000 entrepreneurs from 45 countries. Our study makes three key contributions. First, we contribute to the role of individuals' age in entrepreneurship research by moving beyond the effect of individuals' age on "conventional" entrepreneurial motivation and entry (see e.g., Bönte et al. 2009; Curran and Blackburn 2001; Levesque and Minniti 2006; Minola et al. 2016) to consider the goals these individuals pursue via their organizations. Our results show a U-shaped relationship between entrepreneurs' age and their willingness to contribute to the welfare of their communities and societies, complementing the "classic" view of an inverted U-shaped relationship between individuals' age and entrepreneurship. Second, our study advances and extends the current discourse on (multiple) value creation goals in entrepreneurship by showing that economic and 
social goals display different age patterns across entrepreneurs' lifespan (Brieger and De Clercq 2019; Hechavarría et al. 2017; Hörisch et al. 2017, 2019). Third, we show that the quality of the institutional environment where entrepreneurs operate moderates the relationship between entrepreneurs' age and entrepreneurial value creation goals. By linking lifespan developmental psychology and institutional theory, we provide a deeper understanding of when entrepreneurs prioritize social over economic objectives throughout their lifespans and across institutional conditions. Even if the cross-sectional design of our study does not allow to draw any conclusion as to whether entrepreneurs change their value creation goals over their lifespan, our results provide initial evidence that entrepreneurs in different age groups pursue different social value creation goals through their businesses.

\section{Theoretical background}

\subsection{Entrepreneurship and social value creation}

An increasing number of entrepreneurs prioritize social value creation. By following not only commercial but also social objectives in doing business, entrepreneurs seek to contribute to the natural (e.g., clean and healthy environment) and social (e.g., relatedness, social cohesion, and security) resource endowment, and sometimes forgo their own advantages (e.g., in the form of higher incomes) in the interest of the common good and welfare of their societies (Brieger and De Clercq 2019; Dacin et al. 2010; Terjesen 2017).

Typically, entrepreneurs create both social and economic value at the same time. Economic and social value creation can complement each other, such as when an organization's profits are used to provide goods and services that meet social needs, i.e., philanthropic and charitable activities. For instance, Microsoft has created enormous social impact, even if social value creation was never its primary goal (Acs et al. 2013). More than one billion computers around the world use Microsoft's software for business and home applications, thereby improving the skills and opportunities of millions of people (Acs et al. 2013). Another example is the startup company Celise that produces corn starch-based straws, lids, utensils, and other products that address people's needs for biodegradable and compostable products. Celise founder Cameron Ross simultaneously creates economic and social value creation, illustrating that commercial and social orientation is not a binary choice, but rather a matter of varying degrees.

Since entrepreneurs who also create social value with their ventures can play vital roles in alleviating social problems, protecting the environment, and enhancing their societies' well-being and social cohesion, questions arise concerning the drivers of social value creation. Recent research identifies both individual (e.g., gender, education, income) and contextual (e.g., wealth, culture, institutions) characteristics, as well as their interplay, as important determinants of entrepreneurs' social value creation (Brieger and De Clercq 2019; Brieger et al. 2019; Hechavarría et al. 2017; Terjesen 2017). The burgeoning literature is unclear as to whether there are age-related patterns in the extent to which entrepreneurs create social value.

\subsection{Lifespan Developmental Psychology}

Lifespan developmental psychology focuses on human beings' development of psychological functioning over their life courses (Baltes 1987; Baltes et al. 2006), and posits that human life is a continuous development, and no age period dominates. The normative regularities in age groups (Kanfer and Ackerman 2004) suggest that individuals at every life stage have the potential to change and grow (Baltes et al. 2006). Erikson's (1959, 1994) stage model of lifespan psychological development postulates that adult development is epitomized by major challenges resulting from biological and cultural imperatives which, in turn, impinge on people's social life (Srivastava et al. 2003) and systematically affect people's goals over their lifespans (Carstensen et al. 1999).

Career development follows a normative path from birth to late adulthood (e.g., Super 1980) with three distinct lifespan phases: young, middle, and late adulthood each associated with specific developmental tasks. Individuals who successfully master these tasks can move to the next life phase (Kanfer and Ackerman 2004). According to lifespan psychology, young adulthood is a period of exploration and establishment characterized by a search for identity (Erikson 1994). Young adults focus on social relations and peers while developing their own identities. Moreover, young adults usually live in financially secure circumstances, due to a close affiliation to their parental home. Hence, young adults pursue their individual life plans based on 
personal values and preferences, rather than focusing on mere economic objectives. Individuals develop their objectives according to how much time they perceive that they have left (Carstensen 1995). As young adults perceive time as open-ended, they prioritize goals aimed at improving the world and "this also includes goals related to the task of finding out about one's role in the society (e.g., receiving social acceptance)" (Lang and Carstensen 2002, p. 125). This unconditional orientation towards social relations is also supported by previous research on lifespan developmental changes, suggesting that younger individuals particularly value recognition, social embeddedness, and affiliation to a social group, such as peers or the community they live in, while forming their own social identities (e.g., Lang and Carstensen 2002).

Middle adulthood is a period of growth and maintenance. In middle adulthood, individuals direct their responsibilities towards supporting their own family, providing a home, raising offspring, and caring for elderly (Schaie 2016). The middle-aged adult falters between generativity, i.e., raising own children and thus guiding the next generation, and stagnation, i.e., earning money, generating wealth, and being self-centered. Due to heavy financial obligations, parenthood burdens, and high demands for family support, middle-aged adults are forced to foster goals and pursue an occupation that successfully manages these life stage challenges (Levinson 1986; Warr 2008).

Finally, late adulthood is a period of increasing conscientiousness (Roberts et al. 2006) where individuals tend to critically evaluate their achievements in life and question their ability to make realizable improvements (Erikson 1994). Lifespan research suggests that perceived future time left, and with it remaining opportunities, also predicts cognitive, emotional, and motivational changes potentially causing personal goal shifts (Carstensen 2006; Lang and Carstensen 2002). Older people oftentimes realize that their time is limited, and shift their priorities from their own career advancement to greater generativity, i.e., assuming responsibility for the current young generation, sharing knowledge and experiences, and giving something back to society after a rewarding professional career (Clegg and Fifer 2014; Funken and Gielnik 2015; Kooij et al. 2011; Lang and Carstensen 2002; Zacher et al. 2012). Consequently, growth motives play a subordinate role in late adulthood compared to middle adulthood (Kooij et al. 2011). Also, with increasing age, individuals prioritize emotionally meaningful goals in order to gain personal satisfaction (Kooij et al. 2011; Lang and Carstensen 2002).

Before discussing how entrepreneurs' age may relate to social value creation under a lifespan psychology perspective, it is important to clarify the boundaries of our study. Historically, lifespan developmental psychology applies both cross-sectional and longitudinal designs to study age effects, across a wide range of disciplines such as business and social psychology, organizational behavior, and entrepreneurship (Allemand et al. 2007; Katz et al. 2019; Mackenzie et al. 2018; Nurmi 1989). Key to the understanding study design in lifespan developmental psychology are the concepts of age, cohort, and period effects, and their underlying differences (Schaie 1965). Cross-sectional designs helps to understand variations among people who are in different stages of their life (Mackenzie et al. 2018; SalmelaAro and Upadyaya 2018). As summarized by Schmidt and Teti (2005, p. 5), "this research approach stems from the assumption that when an older age group is drawn from the same population as a younger age group, the eventual behavior of the younger group can be predicted from the behavior of the older group (Achenbach 1978). Thus, a researcher can examine the relationship between earlier and later behavior without actually waiting for development to occur (Achenbach 1978)." Importantly, such cross-sectional age differences do not permit inferences about intra-individual changes and differences over time, but rather provide information about age changes or inter-individual differences in intraindividual change. A limitation of these studies is that their external validity (i.e., generalizability) is possibly affected by historical and cultural differences between cohorts, i.e., cohort effects. However, lifespan psychology highlights that cross-sectional designs are beneficial in that period effects are less likely to influence age differences (Ebner et al. 2006; Lindenberger and Baltes 1997). Longitudinal designs are advantageous in allowing "direct inferences about intra-individual change and inter-individual differences in intraindividual change" (Lindenberger and Baltes 1997, p. 430). However, they are often also susceptible to a (single) cohort effect since the particular cohort under investigation may possess some unique characteristics or experience some unusual event that makes it unlike another cohort of the same age (Schmidt and Teti 2005); this, in turn, might impact the internal and external validity. Moreover, the validity of a simple longitudinal research study can be threatened by the age at the time of 
measurement (Schmidt and Teti 2005); this threat is most likely to impact such studies because it consists of only one cohort and thus makes it impossible to separate out the independent effects of age and time of measurement. In line with previous studies (Ebner et al. 2006; Minola et al. 2016; Nurmi 1989; Wiernik et al. 2013), we apply lifespan developmental psychology in a cross-sectional design to study the implications of age differences for social value creation at the present point in time; we are interested in investigating age group differences in entrepreneurs' social creation goals. Accordingly, we do not investigate how social value creation change as entrepreneurs mature (cf., Wiernik et al. 2013).

\section{Hypotheses}

\subsection{Entrepreneurs' age and social value creation}

We argue that entrepreneurs' individual attitudes, goals, desires, and values differ depending on their age; such differences, in turn, are reflected in their businesses' varied value creation goals. This argument is in line with research on the micro-foundations of organizational goals suggesting that "an organization's goals may be largely set by and reflect the interests, knowledge, and contingencies of a dominant coalition often located at the levels of senior management, the organization's founders, and/or its owners" (Linder and Foss 2018, p. 49).

Since priorities shift with age, entrepreneurs' willingness to create economic or non-economic social value with their entrepreneurial activities should depend on their life stages. We hypothesize that entrepreneurs in middle adulthood will prioritize personal growth and establishment (cf. Minola et al. 2016). As middle-aged adults focus on growth-oriented goals regarding all kinds of life topics and must handle greater financial obligations to their families (Ebner et al. 2006), middleaged entrepreneurs will focus more on preventing financial insecurity, generating wealth, and maximizing profits and growth, thereby pursuing economic goals with their businesses (cf. Warr 2008). Accordingly, middle-aged entrepreneurs will prioritize economic considerations in doing business.

On the other hand, entrepreneurs in young and late adulthood may display a higher willingness to pursue social objectives to contribute to their communities and societies' welfare. Young entrepreneurs often receive (economic) support from their family and community. Under conditions of financial security, young entrepreneurs' basic needs are often met which can increase their motivation to help others and therefore prioritize social value creation when structuring and running ventures. As such, entrepreneurs in young adulthood are more inclined to follow their own life plans based on personal values and preferences, and are less likely to focus on commercial goals. Moreover, young entrepreneurs usually perceive time as open-ended and therefore prioritize world-improving goals. These preferences are illustrated by a famous quote attributed to Winston Churchill: "If a man is not a socialist by the time he is 20 , he has no heart. If he is not a conservative by the time he is 40 , he has no brain." Previous research on entrepreneurial intentions supports this notion, suggesting that compared to older counterparts, younger individuals are more socially oriented, showed by higher engagement in social entrepreneurship compared to older individuals (Lepoutre et al. 2013; Stephan et al. 2015; Terjesen et al. 2016, Terjesen 2017).

Addressing social goals, beyond mere economic goals, should also be more common for entrepreneurs in late adulthood when family and career obligations are usually less extensive and prominent (Kautonen et al. 2017). For instance, career development research suggests that older entrepreneurs have usually already achieved their major career goals resulting in a satisfactory income level (Gielnik et al. 2012). Hence, older individuals consider entrepreneurial activities only as an additional source of income, not as a "principal wealth generator" (Heimonen 2013, p. 55). Older entrepreneurs can thus concentrate on goals related to societal wellbeing and a healthy environment. In addition, older adults typically show higher levels of conscientiousness. Prior research on adult development and value transitions emphasizes that when individuals go from midlife to old age, their value orientation shifts from "instrumental" (such as financial security) to "terminal" values (such as the desire for world peace) (Ryff and Baltes 1976; as cited by Kanfer and Ackerman 2004). Numerous studies suggest that older individuals place less priority on financial gains and personal wealth (Heimonen 2013; Singh and DeNoble 2003; Warr 2008), and instead prioritize recognition, social embeddedness, and affiliation to a community (Lang and Carstensen 2002). Extending these arguments to the realm of entrepreneurship, we expect that older 
entrepreneurs will prioritize social value creation goals more over economic ones than middle-aged entrepreneurs. Taken together, we hypothesize a curvilinear relationship between entrepreneurs' age and their social goals:

\section{Hypothesis 1: There is a U-shaped relationship between an entrepreneur's age and his/her social value creation.}

\subsection{Entrepreneurs' age and social value creation:} the moderating role of institutional quality

Institutions are defined as "persistent and connected sets of rules (formal and informal) that prescribe behavioral roles, constrain activity, and shape expectations" (Keohane 1989, p. 3) and can be distinguished as formal institutions, which include rules and laws, and as informal institutions such as values, norms, and codes of conduct (North 1990). Formal and informal institutions play a critical role in shaping entrepreneurial activity (Autio et al. 2013; Bowen and De Clercq 2008; De Clercq et al. 2014; Goltz et al. 2015; McMullen et al. 2008). In addition to a direct influence, formal and informal institutions indirectly affect entrepreneurship by moderating relationships between individual characteristics (e.g., gender, income, education, social capital) and entrepreneurial intentions and actions (Brieger and De Clercq 2019; De Clercq et al. 2013, 2014; Pathak and Muralidharan 2016; Wennberg et al. 2013).

This study expands this literature by focusing on formal institutions and how the quality of formal institutions moderates the relationship between an entrepreneur's age and his/her choice to create social value with his/her venture. While we do not believe that informal institutions or even socioeconomic development play subordinate roles compared to formal institutions in the relationship between entrepreneurs' age and social value creation, we focus on formal institutions previously shown as instrumental to understanding social entrepreneurial activity (Estrin et al. 2013a, b, 2016; Sahasranamam and Nandakumar 2018; Stephan et al. 2015). Moreover, previous research highlights that high-quality formal institutions are usually associated with certain cultural characteristics and socioeconomic development (Inglehart and Welzel 2005; Welzel 2013).

Formal institutional quality is linked to guaranteed economic freedoms (e.g., property ownership, fully realized freedoms of movement of labor and goods, freedom to invest), political freedoms (e.g., guaranteed free and fair elections, transparent, predictable, and accountable governance, policymaking and administration, and absence of corruption), and social freedoms (e.g., equality before the law, equal access to resources, and freedom of institutional discrimination) (De Haan and Sturm 2003; House 2014; Sigman and Lindberg 2019). Societies with high-quality institutions guarantee these types of freedoms and thus provide the ideal environment for entrepreneurs to start and grow a successful business. As such, formal institutional quality is often proposed as a key driver for entrepreneurship (e.g., Estrin et al. 2013a; Goltz et al. 2015). Economic, political, and social freedoms create economic opportunities and help entrepreneurs to mobilize crucial resources, providing them with the voice and choice to make autonomous economic decisions, and guaranteeing entrepreneurs equal access to resources as well as equality before the law. Such favorable conditions typically reduce transaction costs of entrepreneurial activity, i.e., cheap and less time-consuming entry regulations reduce barriers to new firm creation (Djankov et al. 2002; Klapper et al. 2006). High-quality institutions also enable and help financial institutions and other service providers to develop, thereby facilitating entrepreneurs' access to capital and resources for scaling their entrepreneurial initiatives (Estrin et al. 2013a). As a consequence, greater levels of entrepreneurial activity are typically found in contexts characterized by less regulation of credit and labor, lower levels of corruption, and a smaller government sector (Aidis et al. 2012; Nyström 2008; van Stel et al. 2007).

We hypothesize that institutional quality moderates the curvilinear relationship between entrepreneurs' age and their social value creation goals in doing business. High-quality institutions provide entrepreneurs with the liberty, security, capabilities, and accountability to set goals in accordance with those associated with their position in the life phase (see hypothesis 1 above). When embedded in an environment with strong and well-designed institutions, middle-aged entrepreneurs may feel more comfortable that they will be able to harvest the economic fruits of their efforts and initiatives. High-quality institutions should empower entrepreneurs in their ambitions to initiate or accelerate their business' transformations. Investments and hard work are required to achieve economic profits. In strong institutional environments, entrepreneurs also know that 
their entrepreneurial plans and actions are more predictable and less susceptible to external influences, thereby increasing feelings of control over financial risks and returns (Estrin et al. 2013a; Harper 2003; McMullen et al. 2008). Favorable access to resource endowments, distributed power, equality, security, and accountability should motivate middle-aged entrepreneurs to realize higher economic goals, while empowering younger and older entrepreneurs to follow their noncommercial goals to a larger extent. In environments where people have a political voice and freedom to express themselves, where governments and administrations are accountable and transparent, and economic and political institutions provide resources that create a sense of safety and security, entrepreneurs of younger and older ages should be more empowered to follow their stronger prosocial intentions. To conclude, under a stronger institutional context, middle-aged entrepreneurs should be able to better realize their innate orientation towards achievement, wealth, and financial security, resulting in lower social value creation. Conversely, in such institutional settings, entrepreneurs in early and late adulthood should be better able to realize their innate orientation towards world-improving goals and giving back to society, respectively. Given the above, under a stronger institutional context, the U-shaped relationship between entrepreneurs' age and social value creation should be steepened.

On the other hand, we expect the U-shaped relationship between entrepreneurs' age and their social objectives to flatten in contexts marked by weaker institutions. Weak institutional settings limit entrepreneurs' decision making towards varying value creation goals. Weak institutional environments demand entrepreneurs who prioritize social value creation to fill institutional voids, but cannot provide the sufficient resources that entrepreneurs need to pursue noncommercial goals. Contexts with weak economic, political, and social freedoms tend to be economically poorer and more collectivistic, thus motivating entrepreneurs to focus primarily on the welfare of their ingroup and not of the wider society or all humanity. So, even if entrepreneurs in young and late adulthood would like to create social value to a larger extent, they are unable to do so. In line with this, Brieger et al. (2019) argue that entrepreneurs who are empowered existentially, psychologically, and institutionally tend to be more enabled, motivated, and entitled to pursue broader social goals with their businesses. Low institutional quality also limits entrepreneurs' willingness to pursue economic goals in middle adulthood despite middle-aged entrepreneurs actually prefer to be economically oriented with their venture in this life phase. This is because low institutional quality increases transaction costs, which in turn may reduce financial rewards. Threats due to missing property rights, poor law enforcement, heavy bureaucratic burdens, corruption, and unequal access to resources or inequality before the law should reduce entrepreneurs' willingness to pursue economic goals in middle adulthood. Hence, while well-functioning institutions allow entrepreneurs to follow their innate orientations (whatever that would be), weak institutions limit them. Taken together, we hypothesize:

\section{Hypothesis 2: A country's institutional quality strengthens the $U$-shaped relationship between an entrepreneur's age and his/her social value creation.}

Figures 1 and 2 summarize and visually illustrate our two hypotheses.

\section{Methodology}

\subsection{Sample}

We utilize the Global Entrepreneurship Monitor's (GEM) Adult Population Survey (APS), the largest multi-country research project on entrepreneurship providing individual and country-level harmonized data on entrepreneurial attitudes, intentions, and efforts in over 100 countries (Bergmann and Stephan 2013; Hörisch et al. 2017, 2019; Reynolds et al. 2004). In 2009, GEM included a special topic on commercial, social, and environmental entrepreneurial activity. Entrepreneurs in more than 50 countries answered questions related to their business objectives, and the responses provide the basis for our dependent variable. GEM follows a cross-sectional design, and is therefore most powerful when combined with other data using multilevel research methodology (Bergmann and Stephan 2013; Bosma 2013). We incorporate macro-level data from the World Bank and Freedom House. Our sample represents each country's adult working population (1864 years). In line with previous research, the sample is weighted to each country's census adult labor force 


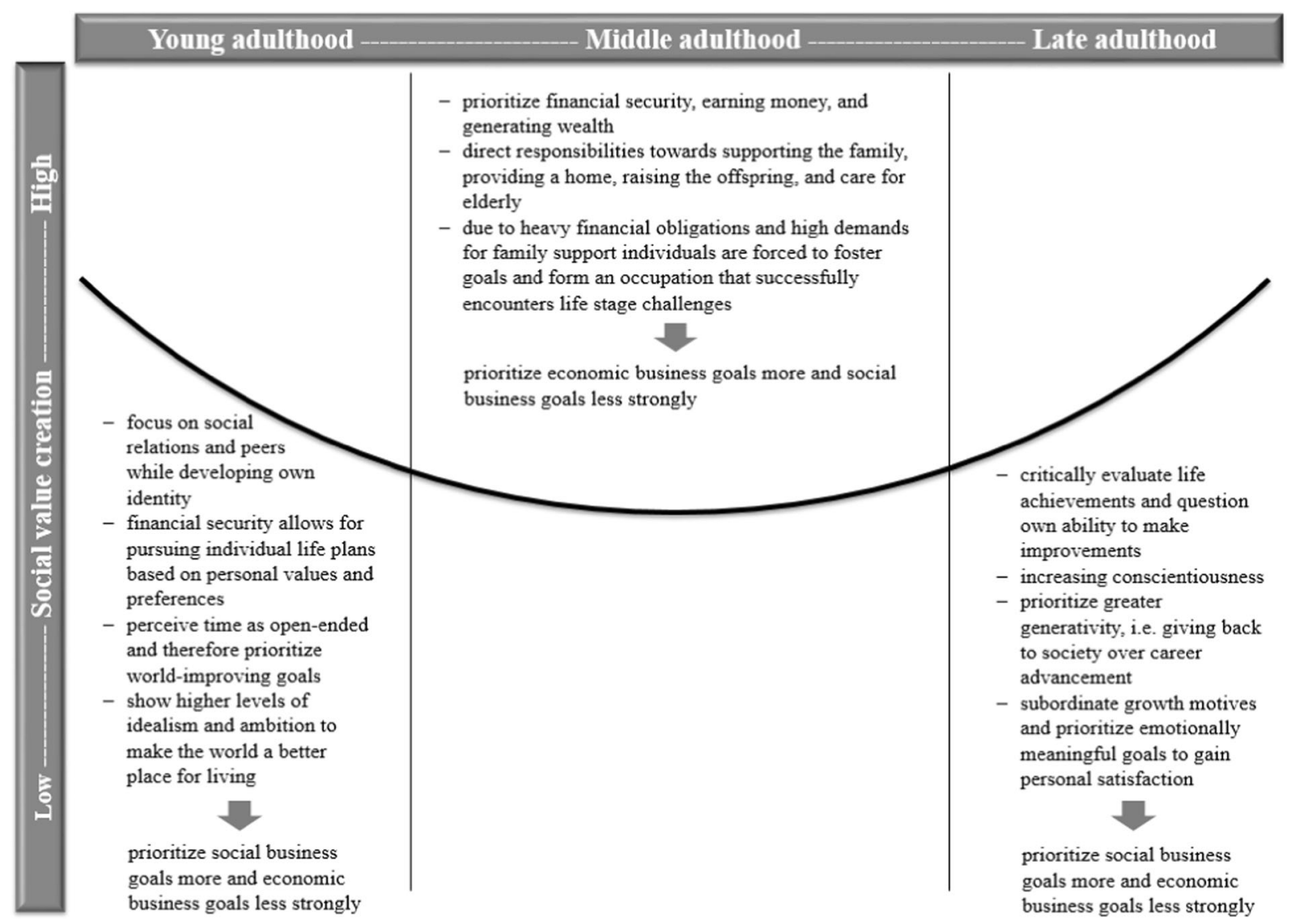

Fig. 1 Relation between entrepreneurs' age and social value creation (Hypothesis 1)

(Hechavarría et al. 2017). Since the World Bank does not provide information for all countries in GEM (Lepoutre et al. 2013; Terjesen et al. 2012), our final sample comprises data from 15,339 entrepreneurs in 45 countries. The countries represent all regions around the world ranging from less developed to highly developed countries.

\subsection{Measures}

Dependent variable Our dependent variable captures the degrees to which an entrepreneur prioritizes social value creation in doing business with the statement: "Organizations may have goals according to the ability to generate economic value, societal value, and environmental value. Please allocate a total of 100 points across these three categories as it pertains to your [venture's] goals." Since the measure is ipsative and social value creation includes both societal well-being and environmental health (Brickson 2007; Mair and Marti 2006; Dacin et al. 2010, 2011), we use the additive score of points allocated to the two types of non-economic business goals, and label the variable "social value creation." Previous research on social and environmental value creation, which used the same items, finds that various individual-level (e.g., gender, education, and income) and country-level characteristics (e.g., wealth and emancipative values) influence entrepreneurs' noncommercial orientations (Brieger and De Clercq 2019; Brieger et al. 2019; Hechavarría et al. 2017; Hörisch et al. 2017, 2019).

Independent variable Our independent variable is each entrepreneur's age measured as a continuum from 18 to 64. We include the quadratic term of age (age squared) to test for curvilinear effects. Research shows that age plays an important role for people's "conventional" entrepreneurial motivation and entry (Bönte et al. 2009; Levesque and Minniti 2006; Minola et al. 2016). For instance, Minola et al. (2016) find evidence for curvilinear lifespan patterns in entrepreneurial desirability and feasibility beliefs. 


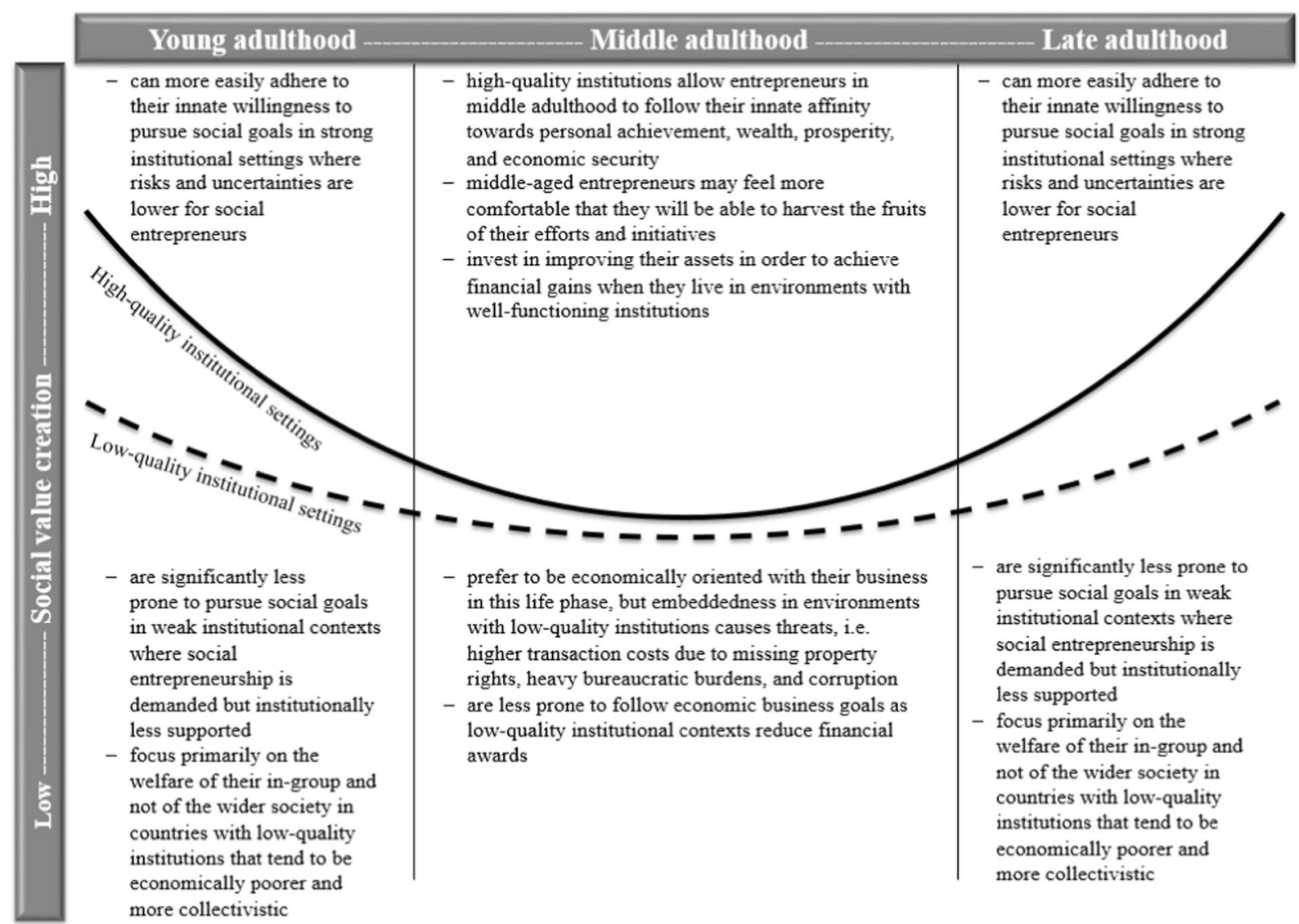

Fig. 2 Relation between entrepreneurs' age, institutional quality, and social value creation (Hypothesis 2)

Moderating variables Institutional quality is measured by three components: (1) economic freedom, (2) political freedom, and (3) social freedom. Economic freedom captures each entrepreneur's country's formal institutional quality with Heritage's Index of Economic Freedom (IEF). IEF measures 12 specific components of economic freedom, scaled from 0 to 100: property rights, judicial effectiveness, government integrity, tax burden, government spending, fiscal health, business freedom, labor freedom, monetary freedom, trade freedom, investment freedom, and financial freedom. The index weights each category equally and averages them to produce an overall economic freedom score (for a detailed description see Miller et al. 2018). We normalized the index into a scale ranging from 0 (least economic freedom) to 1 (most economic freedom). Nyström (2008) shows that economic freedom positively relates to "conventional" entrepreneurship, and McMullen et al. (2008) find a positive association of property rights and opportunity-driven entrepreneurial activity. Both Estrin et al. (2013b) and Hoogendoorn
(2016) show a positive influence of rule of law on social entrepreneurial activity.

Political freedom combines two Freedom House measures of liberty: civil liberty and political rights. Civil liberty encompasses the freedom of the press, the rights of people to assemble, hold alternative political and religious views, receive a fair trial, and express their views without fear of physical retaliation. Political rights include free and fair elections, the ability to form political parties, and popular sovereignty. The scores of both scales range from 1 (greatest degree of freedom) to 7 (smallest degree of freedom). We rescaled both measures according to the country's highest degree of freedom and then normalized the scales from 0 for least political freedom to 1 for most political freedom. Finally, we averaged both scales to one political freedom index. Data are from the year 2008. Past research finds a positive relationship between civic entitlements in form of autonomy rights and political participation rights and social value creation in entrepreneurship (Brieger et al. 2019). Sahasranamam and Nandakumar 
(2018) also show that political institutions positively moderate the positive effect of individual human capital and financial capital on social entrepreneurship.

Social freedom is a combined index based on VDem's egalitarian component index and V-Dem's equality before the law and individual liberty index, and thus measures a country's degree of equality before the law, individual liberty, equal distribution of resources and power, and equal protection of rights. We averaged both scales, which range from 0 for weak social freedom to 1 for strong social freedom. The V-Dem data are from the year 2008. The role of social freedom for entrepreneurial activity has not yet been explored. However, Pathak and Muralidharan (2018) recently show that income inequality increases people's likelihood to be engaged in social entrepreneurship, while income mobility decreases it.

Control variables Consistent with previous GEM research, we include individual and country-level control variables. At the individual level, we control for individuals' gender, household income, education, household size, personal trait characteristics such as having start-up skills or fearing failure, and if the respondent knows an entrepreneur. Female gender is significantly associated with social value creation in doing business (Brieger et al. 2019; Hechavarría et al. 2017). Several studies document that education positively relates to socially oriented entrepreneurial activity (Brieger and De Clercq 2019; Brieger et al. 2019; Estrin et al. 2013b, 2016; Pathak and Muralidharan 2016; Stephan et al. 2015). Prior studies report mixed results for household income. Brieger and De Clercq (2019) document that household income is negatively associated with entrepreneurs' social value creation goals. On the contrary, Pathak and Muralidharan (2016) and Sahasranamam and Nandakumar (2018) report a positive relationship of household income and social entrepreneurship. Household size is negatively linked to entrepreneurs' social value creation (Brieger and De Clercq 2019; Brieger et al. 2019). Start-up skills (Pathak and Muralidharan 2016; Sahasranamam and Nandakumar 2018), fear of failure (Estrin et al. 2013b), and knowing another entrepreneur (Estrin et al. 2013b; Sahasranamam and Nandakumar 2018) are positively related to social entrepreneurship. Brieger et al. (2019) report a negative relationship between entrepreneurs' fear of failure and level of social value creation.
At the country level, we control for GDP per capita, GDP growth, and unemployment. Hoogendoorn (2016) and Brieger and De Clercq (2019) provide evidence for a positive relationship between GDP and socially oriented entrepreneurial activity. Several countries also include GDP growth and unemployment as controls, but both variables are mostly insignificantly related to socially oriented entrepreneurial activity (Brieger et al. 2019; Estrin et al. 2013b).

\subsection{Data analysis}

We test our hypotheses with multilevel mixed-effects linear regression. Our dataset's nested nature (individuals nested in countries) renders multilevel modeling preferable to traditional regression techniques which tend to generate inefficient estimates and biased standard errors (Snijders and Bosker 2012). To determine the need for multilevel modeling, we estimated the between-country variance of the dependent variables. We run an intercept-only model for our dependent variable and calculate an intraclass correlation coefficient (ICC; the percentage of total variance in the respective dependent variable that exists between countries). We find that about $14.5 \%$ of social value creation variations lie between countries. ICCs are considered small, medium, and large at $0.05,0.10$, and 0.15 respectively (Hox 2010). Hence, the results indicate that there is enough between-country variance to warrant a multilevel approach. We use Stata 15's "mixed" command to conduct the multilevel linear regression. For our interaction models, we specify a multilevel linear regression with a random intercept and a random slope for the age variable (Table 1).

\section{Results}

\subsection{Main results}

Table 2 depicts our variables' descriptive statistics. On average, entrepreneurs give much less priority to social value $(M=35.94, \mathrm{SD}=25.59)$ than economic value creation. The entrepreneurs' average age is 41 years $(S D=11.72)$, and $37 \%$ of the participants are female. Nearly $37 \%$ of the entrepreneurs have at least postsecondary education $(M=2.05, \mathrm{SD}=1.00)$, and more than half are in the upper third household income range $(M=1.42, \mathrm{SD}=0.73)$. Most entrepreneurs report 
Table 1 Variables description

\begin{tabular}{|c|c|}
\hline Variable & Description \\
\hline \multicolumn{2}{|c|}{ Individual-level variables } \\
\hline $\begin{array}{l}\text { Social value } \\
\text { creation }\end{array}$ & $\begin{array}{l}\text { Allocate a total of } 100 \text { points across three categories of value creation goals: economic, environment, and social. } \\
\text { Social value creation is an additive of each entrepreneur's willingness to create social and environmental value } \\
\text { with his or her business. }\end{array}$ \\
\hline Age & Age in years (linear and squared). \\
\hline Gender & Female $(=1 ; 0=$ male $)$. \\
\hline Household income & Lowest third $(=0)$, middle third $(=1)$, or upper third $(=2)$ household income distribution in the country of living. \\
\hline Education & $\begin{array}{l}\text { No educational background }(=0) \text {, some secondary education }(=1) \text {, secondary education }(=2) \text {, post-secondary } \\
\text { education }(=3) \text {, or graduate experience }(=4) \text {. }\end{array}$ \\
\hline Start-up skills & Has the knowledge, skill, and experience to start-up a business ( $=1,0=$ otherwise). \\
\hline Fear of failure & Would not start a business out of fear of failure $(=1,0=$ otherwise $)$ \\
\hline $\begin{array}{l}\text { Knows } \\
\text { entrepreneur }\end{array}$ & Knows someone who has started a business in the past 2 years $(=1,0=$ otherwise). \\
\hline Household size & One household members $(=1)$ to five and more household members $(=5)$. \\
\hline \multicolumn{2}{|c|}{ Country-level variables } \\
\hline GDP p.C. (t-1) & Gross domestic product (GDP) per capita (constant 2010 US\$). Source: World Bank, 2008 data. \\
\hline $\begin{array}{l}\text { GDP growth p.C. } \\
(\mathrm{t}-1)\end{array}$ & GDP growth per capita (annual \%). Source: World Bank, 2008 data. \\
\hline $\begin{array}{l}\text { Unemployment } \\
(\mathrm{t}-1)\end{array}$ & Percentage of unemployed individuals among the working population. Source: World Bank, 2008 data. \\
\hline $\begin{array}{l}\text { Economic freedom } \\
(\mathrm{t}-1)\end{array}$ & $\begin{array}{l}\text { Economic freedom is measured by the Index of Economic Freedom which assesses conditions in the four aspects of } \\
\text { institutional quality rule of law, government size, regulatory efficiency, and market openness. We normalized the } \\
\text { index into a scale range with minimum } 0 \text { for least economic freedom and maximum } 1 \text { for most economic freedom. } \\
\text { Source: Heritage, } 2008 \text { data. }\end{array}$ \\
\hline $\begin{array}{l}\text { Political freedom } \\
\text { (t-1) }\end{array}$ & $\begin{array}{l}\text { Political freedom is measured by the Freedom House measured of liberty: civil liberty and political rights. The scores } \\
\text { of both scales range from } 1 \text { (greatest degree of freedom) to } 7 \text { (smallest degree of freedom). We rescaled both } \\
\text { measures according to the country's highest degree of freedom, and then normalized the scales to } 0 \text { for least } \\
\text { political freedom to } 1 \text { for most political freedom. Finally, we averaged both scales to one political freedom index. } \\
\text { Source: Freedom House, } 2008 \text { data. }\end{array}$ \\
\hline $\begin{array}{l}\text { Social freedom } \\
(\mathrm{t}-1)\end{array}$ & $\begin{array}{l}\text { Social freedom is a combined index based on V-Dem's (1) egalitarian component index and (2) equality before the } \\
\text { law and individual liberty index. We averaged both scales, which range from } 0 \text { for weak social freedom to } 1 \text { for } \\
\text { strong social freedom. Source: V-Dem, } 2008 \text { data. }\end{array}$ \\
\hline
\end{tabular}

$\mathrm{t}-1$ indicates lagged variables

having the skills to start and run a business $(M=0.83$, $\mathrm{SD}=0.37)$ and less than one third of entrepreneurs indicate a fear of failure $(M=0.29, S D=0.45)$. In addition, more than half of the entrepreneurs report knowing other entrepreneurs $(M=0.58, \mathrm{SD}=0.49)$. The institutional quality variables economic freedom $(M=0.65$, $\mathrm{SD}=0.10)$, political freedom $(M=0.74, \mathrm{SD}=0.30)$, and social freedom $(M=0.78, \mathrm{SD}=0.19)$ indicate a good variance in our sample. Table 3 depicts countrylevel descriptive statistics.

Table 4's correlation matrix shows no significant bivariate relationship between social value creation and age $(r=0.01$, n.s.), while social value creation is positively associated with the institutional variables economic freedom $(r=0.13, p<0.01)$, political free$\operatorname{dom}(r=0.07, p<0.01)$, and social freedom $(r=0.08$, $p<0.01)$. We also find positive significant bivariate relationships between social value creation and gender ( $r=0.03, p<0.01)$, education $(r=0.11, p<0.01)$, knows entrepreneur $(r=0.02, p<0.01)$, and GDP $\mathrm{p}$. C. $(r=0.15, p<0.01)$. Social value creation is negatively related to household income $(r=-0.03$, $p<0.01)$, fear of failure $(r=-0.03, p<0.01)$, household size $(r=-0.06, p<0.01)$, GDP growth p. C. $(r=$ $-0.09, p<0.01)$, and unemployment $(r=-0.07$, $p<0.01)$.

Table 5 contains the results of our multilevel regression models: Model 1 examines the controls. Model 2 
explores the direct effect of age on social value creation. Model 3 adds the quadratic age term to test the curvilinear effect of age on social value creation. Models 4-6 include the interaction terms.

Model 1 results show significant associations of entrepreneurs' value creation goals and gender, income, education, GDP, and unemployment. Models 2 and 3 report the age effects on social value creation. Model 2 reports a significant negative linear age term $(\beta=-0.095 ; p<0.01)$. Model 3 results indicate a U-shaped pattern for the relationship between age and social value creation. As expected, the coefficient of the linear term is negative and significant $(\beta=-0.088 ; p<0.01)$, whereas the coefficient of the squared term is positive and significant $(\beta=0.006 ; p<0.01)$. The significant U-shaped relationship is stable across all models, supporting Hypothesis 1 .

Models 4-6 include the interaction terms. The results show that institutional quality strengthens the U-shaped structure between age and social value creation. Model 4 results indicate that economic freedom reinforces the negative linkage between age and social value creation $(\beta=-0.573 ; p<0.1)$ and positively moderates the positive association of age squared and social value creation $(\beta=0.049 ; p<0.01)$. The results of Models 5 and 6 indicate that political $(\beta=0.016 ; p<0.01)$ and social freedom $(\beta=0.026 ; p<0.01)$ positively and significantly moderate the positive relationship between age squared and social value creation. Thus, we can partially support Hypothesis 2 .

To better understand the nature of the U-shaped relationship between entrepreneurs' age and social value creation, we plot the corresponding graphs. Figure 3 shows a U-shaped relationship between age and social value creation, indicating that entrepreneurs become more economically oriented when they reach middle age and more socially oriented in young and old age. Entrepreneurs' creation of social value decreases with age to a turning point, after which social value creation increases again with rising age. Notably, as we only include entrepreneurs aged 18-64 years, the increase in social value creation with higher age is limited by the restriction. But if we also consider those entrepreneurs who are older than 64 years old, the graph is even more strongly U-shaped as older entrepreneurs tend to report high levels of social value creation.

Figures 4, 5 and 6 show that the curvilinear relationships are moderated by the institutional quality variables economic freedom, political freedom, and social freedom. While strong economic freedom strengthens and thus steepens the U-shaped relationship between entrepreneurs' age and social value creation, weak economic freedom seems to flatten the curve such that the observed curvilinear

Table 2 Descriptive statistics

\begin{tabular}{|c|c|c|c|c|c|}
\hline Variable & $N$ & Mean & SD & Min & Max \\
\hline Social value creation & 15,339 & 35.944 & 25.585 & 0 & 100 \\
\hline Gender (female) & 15,339 & 0.369 & 0.483 & 0 & 1 \\
\hline Age & 15,339 & 41.121 & 11.723 & 18 & 64 \\
\hline Household income & 15,339 & 1.416 & 0.732 & 0 & 2 \\
\hline Education & 15,339 & 2.052 & 1.004 & 0 & 4 \\
\hline Start-up skills & 15,339 & 0.833 & 0.373 & 0 & 1 \\
\hline Fear of failure & 15,339 & 0.286 & 0.452 & 0 & 1 \\
\hline Knows entrepreneur & 15,339 & 0.579 & 0.494 & 0 & 1 \\
\hline Household size & 15,339 & 3.470 & 1.251 & 1 & 5 \\
\hline GDP p.C. & 45 & $23,619.120$ & $21,415.090$ & 1237.677 & $90,806.840$ \\
\hline GDP growth p.C. & 45 & 1.844 & 3.496 & -10.119 & 10.281 \\
\hline Unemployment & 45 & 7.721 & 4.523 & 2.550 & 23.300 \\
\hline Economic freedom & 45 & 0.648 & 0.100 & 0.447 & 0.897 \\
\hline Political freedom & 45 & 0.744 & 0.295 & 0.083 & 1.000 \\
\hline Social freedom & 45 & 0.781 & 0.191 & 0.232 & 0.983 \\
\hline
\end{tabular}


Table 3 Country statistics

\begin{tabular}{|c|c|c|c|c|c|c|c|}
\hline Country & Observations & GDP p.C. & $\begin{array}{l}\text { GDP growth } \\
\text { p.C. }\end{array}$ & Unemployment & $\begin{array}{l}\text { Economic } \\
\text { freedom }\end{array}$ & $\begin{array}{l}\text { Political } \\
\text { freedom }\end{array}$ & $\begin{array}{l}\text { Social } \\
\text { freedom }\end{array}$ \\
\hline Algeria & 174 & 4396.76 & 0.75 & 11.33 & 0.56 & 0.25 & 0.61 \\
\hline Argentina & 271 & $10,125.26$ & 3.00 & 7.89 & 0.54 & 0.83 & 0.83 \\
\hline Belgium & 191 & $44,995.29$ & -0.05 & 6.98 & 0.72 & 1.00 & 0.97 \\
\hline $\begin{array}{l}\text { Bosnia and } \\
\text { Herzegovina }\end{array}$ & 117 & 4566.88 & 5.50 & 23.30 & 0.54 & 0.58 & 0.81 \\
\hline Brazil & 498 & $10,560.24$ & 4.02 & 7.90 & 0.56 & 0.83 & 0.77 \\
\hline Chile & 809 & $12,486.95$ & 2.16 & 7.48 & 0.79 & 1.00 & 0.82 \\
\hline China & 1022 & 3805.03 & 9.09 & 4.20 & 0.53 & 0.08 & 0.37 \\
\hline Colombia & 601 & 6048.08 & 2.33 & 11.42 & 0.62 & 0.58 & 0.58 \\
\hline Croatia & 141 & $14,782.67$ & 2.09 & 8.53 & 0.54 & 0.83 & 0.88 \\
\hline Denmark & 138 & $60,504.51$ & -1.09 & 3.43 & 0.79 & 1.00 & 0.98 \\
\hline Dominican Republic & 411 & 5120.62 & 1.79 & 14.16 & 0.58 & 0.83 & 0.67 \\
\hline Ecuador & 591 & 4624.19 & 4.57 & 7.31 & 0.55 & 0.67 & 0.80 \\
\hline Finland & 220 & $49,366.64$ & 0.25 & 6.37 & 0.75 & 1.00 & 0.97 \\
\hline Germany & 456 & $42,367.62$ & 1.27 & 7.52 & 0.71 & 1.00 & 0.97 \\
\hline Greece & 292 & $29,876.52$ & -0.60 & 7.76 & 0.61 & 0.92 & 0.93 \\
\hline Hong Kong & 41 & $31,553.63$ & 1.52 & 3.56 & 0.90 & 0.58 & 0.90 \\
\hline Hungary & 248 & $13,794.42$ & 1.07 & 7.82 & 0.68 & 1.00 & 0.89 \\
\hline Iceland & 245 & $46,531.31$ & -0.35 & 2.95 & 0.76 & 1.00 & 0.94 \\
\hline Iran & 376 & 5914.61 & -0.20 & 10.48 & 0.45 & 0.17 & 0.48 \\
\hline Israel & 132 & $29,930.69$ & 1.24 & 7.70 & 0.66 & 0.92 & 0.79 \\
\hline Italy & 72 & $37,587.57$ & -1.70 & 6.72 & 0.63 & 0.92 & 0.93 \\
\hline Jamaica & 443 & 5150.36 & -1.28 & 10.33 & 0.66 & 0.75 & 0.73 \\
\hline Japan & 129 & $45,165.88$ & -1.14 & 3.98 & 0.73 & 0.92 & 0.96 \\
\hline Jordan & 261 & 4073.39 & 2.76 & 12.70 & 0.64 & 0.33 & 0.60 \\
\hline Korea & 289 & $20,848.55$ & 2.09 & 3.16 & 0.69 & 0.92 & 0.91 \\
\hline Latvia & 243 & $13,242.73$ & -2.59 & 7.74 & 0.68 & 0.92 & 0.91 \\
\hline Malaysia & 130 & 8991.76 & 1.55 & 3.34 & 0.64 & 0.50 & 0.62 \\
\hline Morocco & 67 & 2705.79 & 4.74 & 9.57 & 0.56 & 0.42 & 0.60 \\
\hline Netherlands & 301 & $52,121.20$ & 1.30 & 2.75 & 0.77 & 1.00 & 0.96 \\
\hline Norway & 236 & $90,806.84$ & -0.86 & 2.55 & 0.69 & 1.00 & 0.98 \\
\hline Panama & 240 & 7691.55 & 6.74 & 5.85 & 0.65 & 0.92 & 0.81 \\
\hline Peru & 421 & 4701.90 & 7.80 & 6.64 & 0.64 & 0.75 & 0.65 \\
\hline Romania & 38 & 8872.78 & 10.28 & 5.79 & 0.62 & 0.83 & 0.83 \\
\hline Russia & 26 & $11,089.93$ & 5.29 & 6.32 & 0.50 & 0.25 & 0.60 \\
\hline Saudi Arabia & 170 & $18,465.97$ & 5.75 & 5.08 & 0.63 & 0.08 & 0.30 \\
\hline Slovenia & 368 & $25,448.94$ & 3.14 & 4.37 & 0.60 & 1.00 & 0.94 \\
\hline South Africa & 141 & 7465.39 & 1.79 & 22.91 & 0.63 & 0.83 & 0.76 \\
\hline Spain & 1663 & $32,304.62$ & -0.48 & 11.25 & 0.69 & 1.00 & 0.95 \\
\hline Switzerland & 216 & $75,424.28$ & 0.99 & 3.35 & 0.80 & 1.00 & 0.97 \\
\hline United Arab Emirates & 200 & $43,045.33$ & -10.12 & 4.01 & 0.63 & 0.25 & 0.60 \\
\hline UK & 1473 & $40,315.57$ & -1.41 & 5.62 & 0.79 & 1.00 & 0.92 \\
\hline USA & 357 & $49,364.64$ & -1.23 & 5.78 & 0.81 & 1.00 & 0.87 \\
\hline Uruguay & 246 & $10,698.08$ & 6.82 & 7.70 & 0.68 & 1.00 & 0.91 \\
\hline
\end{tabular}


Table 3 (continued)

\begin{tabular}{lcrlclll}
\hline Country & Observations & GDP p.C. GDP growth & Unemployment & $\begin{array}{l}\text { Economic } \\
\text { freedom }\end{array}$ & $\begin{array}{l}\text { Political } \\
\text { freedom }\end{array}$ & $\begin{array}{l}\text { Social } \\
\text { freedom }\end{array}$ \\
\hline Venezuela & 98 & $14,687.98$ & 3.61 & 6.85 & 0.45 & 0.50 & 0.64 \\
Yemen & 537 & 1237.68 & 0.76 & 14.97 & 0.54 & 0.33 & 0.23 \\
Mean & 340.67 & $23,619.12$ & 1.84 & 7.72 & 0.65 & 0.74 & 0.78 \\
\hline
\end{tabular}

relationship becomes more linear, indicating lower levels of differences in social value creation among young, middle, and older-aged entrepreneurs. Figures 5 and 6 show that the negative effect of entrepreneurs' age on social value creation does not turn to a positive one at higher ages if entrepreneurs live in countries that are marked by weak political and social freedoms. In countries with weak political and social freedoms, the negative relationship between entrepreneurs' age and social value creation remains stable, which might be explained by the fact that older entrepreneurs have to care more for themselves and their direct family members when they do not have equal rights, equal access to resources and power, or even miss the opportunities to create political and social changes.

\subsection{Robustness checks}

We run several robustness checks to test the robustness of our theorizing and findings. First, because of the cross-sectional nature of our data, one might criticize our findings as influenced by differences between different birth cohorts or selection effects. For example, millennial entrepreneurs might report higher levels of social value creation because this cohort had more exposure to environmental and social issues compared to generation $X$ entrepreneurs. While we cannot completely rule out this possibility in our study, it is worth noting that baby boomer entrepreneurs (individuals born between 1945 and 1964) have similar venture goals as compared with the late millennial entrepreneurs (those individuals born 1983 and 1996) despite being closer to

Table 4 Correlation matrix

\begin{tabular}{|c|c|c|c|c|c|c|c|c|c|c|c|c|c|c|c|}
\hline & 1 & 2 & 3 & 4 & 5 & 6 & 7 & 8 & 9 & 10 & 11 & 12 & 13 & 14 & 15 \\
\hline $\begin{array}{l}\text { 1. Social value } \\
\text { creation }\end{array}$ & 1 & & & & & & & & & & & & & & \\
\hline 2. Gender (female) & 0.03 & 1 & & & & & & & & & & & & & \\
\hline 3. Age & 0.01 & -0.03 & 1 & & & & & & & & & & & & \\
\hline $\begin{array}{l}\text { 4. Household } \\
\text { income }\end{array}$ & -0.03 & -0.10 & -0.01 & 1 & & & & & & & & & & & \\
\hline 5. Education & 0.11 & -0.02 & -0.05 & 0.23 & 1 & & & & & & & & & & \\
\hline 6. Start-up skills & 0.02 & -0.05 & -0.01 & 0.11 & 0.12 & 1 & & & & & & & & & \\
\hline 7. Fear of failure & -0.03 & 0.06 & -0.01 & -0.05 & -0.06 & -0.14 & 1 & & & & & & & & \\
\hline $\begin{array}{l}\text { 8. Knows } \\
\text { entrepreneur }\end{array}$ & 0.02 & -0.07 & -0.17 & 0.11 & 0.09 & 0.12 & -0.03 & 1 & & & & & & & \\
\hline 9. Household size & -0.06 & 0.01 & -0.18 & 0.10 & -0.12 & -0.02 & 0.03 & 0.02 & 1 & & & & & & \\
\hline 10. GDP p.C. & 0.15 & -0.03 & 0.23 & 0.05 & 0.30 & 0.07 & -0.04 & -0.05 & -0.27 & 1 & & & & & \\
\hline $\begin{array}{l}\text { 11. GDP growth } \\
\text { p.C. }\end{array}$ & -0.09 & 0.07 & -0.11 & -0.07 & -0.26 & -0.09 & 0.00 & 0.09 & 0.09 & -0.55 & 1 & & & & \\
\hline 12. Unemployment & -0.07 & -0.01 & -0.14 & 0.00 & -0.12 & 0.04 & 0.06 & -0.04 & 0.16 & -0.44 & -0.09 & 1 & & & \\
\hline $\begin{array}{l}\text { 13. Economic } \\
\text { freedom }\end{array}$ & 0.13 & 0.00 & 0.22 & 0.03 & 0.28 & 0.10 & -0.06 & -0.07 & -0.20 & 0.67 & -0.47 & -0.32 & 1 & & \\
\hline $\begin{array}{l}\text { 14. Political } \\
\text { freedom }\end{array}$ & 0.07 & 0.02 & 0.22 & 0.04 & 0.22 & 0.14 & -0.02 & -0.08 & -0.21 & 0.57 & -0.42 & -0.11 & 0.72 & 1 & \\
\hline 15. Social freedom & 0.08 & -0.01 & 0.24 & 0.06 & 0.23 & 0.14 & -0.03 & -0.06 & -0.23 & 0.66 & -0.44 & -0.23 & 0.67 & 0.92 & 1 \\
\hline
\end{tabular}

Correlations in italics are significant at $p<0.01$. The sample includes 45 countries $(N=15,339)$ 
Table 5 Main results

\begin{tabular}{|c|c|c|c|c|c|c|}
\hline & Model 1 & Model 2 & Model 3 & Model 4 & Model 5 & Model 6 \\
\hline Constant & $\begin{array}{l}27.160^{* * *} \\
(5.029)\end{array}$ & $\begin{array}{l}27.720 * * * \\
(5.072)\end{array}$ & $\begin{array}{l}26.580 * * * \\
(5.118)\end{array}$ & $\begin{array}{l}26.860 * * * \\
(4.826)\end{array}$ & $\begin{array}{l}26.950 * * * \\
(5.572)\end{array}$ & $\begin{array}{l}27.480 * * * \\
(5.476)\end{array}$ \\
\hline \multicolumn{7}{|l|}{ Individual-level controls } \\
\hline Gender (female) & $\begin{array}{l}1.566^{* *} \\
(0.731)\end{array}$ & $\begin{array}{l}1.506^{* *} \\
(0.713)\end{array}$ & $\begin{array}{l}1.575 * * \\
(0.721)\end{array}$ & $\begin{array}{l}1.564 * * \\
(0.717)\end{array}$ & $\begin{array}{l}1.542 * * \\
(0.720)\end{array}$ & $\begin{array}{l}1.527 * * \\
(0.722)\end{array}$ \\
\hline Household income & \multicolumn{6}{|c|}{ Reference $=$ Household income is low } \\
\hline Middle & $\begin{array}{l}-1.024 \\
(0.716)\end{array}$ & $\begin{array}{l}-1.010 \\
(0.713)\end{array}$ & $\begin{array}{c}-0.982 \\
(0.720)\end{array}$ & $\begin{array}{c}-0.796 \\
(0.713)\end{array}$ & $\begin{array}{c}-0.838 \\
(0.716)\end{array}$ & $\begin{array}{l}-0.819 \\
(0.713)\end{array}$ \\
\hline High & $\begin{array}{l}-2.404 * * \\
(0.960)\end{array}$ & $\begin{array}{l}-2.316^{* *} \\
(0.949)\end{array}$ & $\begin{array}{l}-2.268^{* *} \\
(0.946)\end{array}$ & $\begin{array}{l}-2.124 * * \\
(0.926)\end{array}$ & $\begin{array}{l}-2.157 * * \\
(0.932)\end{array}$ & $\begin{array}{l}-2.161 * * \\
(0.932)\end{array}$ \\
\hline Education & \multicolumn{6}{|c|}{ Reference $=$ Education is none } \\
\hline Some secondary & $\begin{array}{l}1.641 \\
(1.168)\end{array}$ & $\begin{array}{l}1.157 \\
(1.221)\end{array}$ & $\begin{array}{l}1.239 \\
(1.224)\end{array}$ & $\begin{array}{l}1.496 \\
(1.208)\end{array}$ & $\begin{array}{l}1.471 \\
(1.207)\end{array}$ & $\begin{array}{l}1.480 \\
(1.200)\end{array}$ \\
\hline Secondary & $\begin{array}{l}1.892 * \\
(0.996)\end{array}$ & $\begin{array}{l}1.175 \\
(1.008)\end{array}$ & $\begin{array}{l}1.278 \\
(1.046)\end{array}$ & $\begin{array}{l}1.486 \\
(1.040)\end{array}$ & $\begin{array}{l}1.475 \\
(1.042)\end{array}$ & $\begin{array}{l}1.517 \\
(1.031)\end{array}$ \\
\hline Post-secondary & $\begin{array}{l}2.431 * \\
(1.278)\end{array}$ & $\begin{array}{l}1.761 \\
(1.329)\end{array}$ & $\begin{array}{l}1.932 \\
(1.366)\end{array}$ & $\begin{array}{l}2.234 * \\
(1.343)\end{array}$ & $\begin{array}{l}2.218^{*} \\
(1.347)\end{array}$ & $\begin{array}{l}2.257 * \\
(1.335)\end{array}$ \\
\hline Graduate experience & $\begin{array}{l}4.971 * * * \\
(1.464)\end{array}$ & $\begin{array}{l}4.521 * * * \\
(1.477)\end{array}$ & $\begin{array}{l}4.756 * * * \\
(1.500)\end{array}$ & $\begin{array}{l}5.020 * * * \\
(1.559)\end{array}$ & $\begin{array}{l}4.997 * * * \\
(1.548)\end{array}$ & $\begin{array}{l}5.039 * * * \\
(1.541)\end{array}$ \\
\hline Start-up skills & $\begin{array}{l}0.303 \\
(0.938)\end{array}$ & $\begin{array}{l}0.286 \\
(0.936)\end{array}$ & $\begin{array}{l}0.358 \\
(0.924)\end{array}$ & $\begin{array}{l}0.447 \\
(0.925)\end{array}$ & $\begin{array}{l}0.419 \\
(0.933)\end{array}$ & $\begin{array}{l}0.418 \\
(0.934)\end{array}$ \\
\hline Fear of failure & $\begin{array}{l}-0.500 \\
(0.707)\end{array}$ & $\begin{array}{l}-0.517 \\
(0.694)\end{array}$ & $\begin{array}{c}-0.478 \\
(0.698)\end{array}$ & $\begin{array}{l}-0.517 \\
(0.699)\end{array}$ & $\begin{array}{l}-0.519 \\
(0.701)\end{array}$ & $\begin{array}{l}-0.531 \\
(0.702)\end{array}$ \\
\hline Knows entrepreneur & $\begin{array}{l}0.651 \\
(0.652)\end{array}$ & $\begin{array}{l}0.336 \\
(0.669)\end{array}$ & $\begin{array}{l}0.348 \\
(0.674)\end{array}$ & $\begin{array}{l}0.320 \\
(0.686)\end{array}$ & $\begin{array}{l}0.309 \\
(0.680)\end{array}$ & $\begin{array}{l}0.298 \\
(0.676)\end{array}$ \\
\hline Household size & \multicolumn{6}{|c|}{ Reference $=$ Household size is one person } \\
\hline 2 persons & $\begin{array}{l}-1.205 \\
(0.928)\end{array}$ & $\begin{array}{l}-1.051 \\
(0.951)\end{array}$ & $\begin{array}{l}-1.257 \\
(0.934)\end{array}$ & $\begin{array}{l}-1.359 \\
(0.922)\end{array}$ & $\begin{array}{l}-1.357 \\
(0.922)\end{array}$ & $\begin{array}{l}-1.380 \\
(0.914)\end{array}$ \\
\hline 3 persons & $\begin{array}{c}-1.424 \\
(0.946)\end{array}$ & $\begin{array}{l}-1.583 * \\
(0.932)\end{array}$ & $\begin{array}{l}-1.490 \\
(0.927)\end{array}$ & $\begin{array}{l}-1.643 * \\
(0.916)\end{array}$ & $\begin{array}{l}-1.670^{*} \\
(0.913)\end{array}$ & $\begin{array}{l}-1.662 * \\
(0.912)\end{array}$ \\
\hline 4 persons & $\begin{array}{l}-1.775^{* *} \\
(0.823)\end{array}$ & $\begin{array}{l}-1.894^{* *} \\
(0.846)\end{array}$ & $\begin{array}{l}-1.645^{* *} \\
(0.822)\end{array}$ & $\begin{array}{l}-1.788^{* *} \\
(0.829)\end{array}$ & $\begin{array}{l}-1.780^{* *} \\
(0.834)\end{array}$ & $\begin{array}{l}-1.746^{* *} \\
(0.837)\end{array}$ \\
\hline 5 persons and more & $\begin{array}{l}-1.683^{*} \\
(0.957)\end{array}$ & $\begin{array}{l}-1.882^{* *} \\
(0.959)\end{array}$ & $\begin{array}{l}-1.764 * \\
(0.952)\end{array}$ & $\begin{array}{l}-1.826^{*} \\
(0.969)\end{array}$ & $\begin{array}{l}-1.821^{*} \\
(0.969)\end{array}$ & $\begin{array}{l}-1.801 * \\
(0.974)\end{array}$ \\
\hline \multicolumn{7}{|l|}{ Country-level controls } \\
\hline GDP p.C./100 & $\begin{array}{l}0.023 * * * \\
(0.007)\end{array}$ & $\begin{array}{l}0.024 * * * \\
(0.007)\end{array}$ & $\begin{array}{l}0.024 * * * \\
(0.007)\end{array}$ & $\begin{array}{l}0.021 * * * \\
(0.007)\end{array}$ & $\begin{array}{l}0.022 * * \\
(0.009)\end{array}$ & $\begin{array}{l}0.019 * * \\
(0.009)\end{array}$ \\
\hline GDP growth p.C. & $\begin{array}{l}-0.088 \\
(0.346)\end{array}$ & $\begin{array}{c}-0.076 \\
(0.344)\end{array}$ & $\begin{array}{l}-0.070 \\
(0.348)\end{array}$ & $\begin{array}{c}-0.058 \\
(0.354)\end{array}$ & $\begin{array}{c}-0.082 \\
(0.378)\end{array}$ & $\begin{array}{c}-0.096 \\
(0.376)\end{array}$ \\
\hline Unemployment & $\begin{array}{l}0.580 \\
(0.367)\end{array}$ & $\begin{array}{l}0.569 \\
(0.371)\end{array}$ & $\begin{array}{l}0.564 \\
(0.374)\end{array}$ & $\begin{array}{l}0.583 \\
(0.374)\end{array}$ & $\begin{array}{l}0.547 \\
(0.371)\end{array}$ & $\begin{array}{l}0.553 \\
(0.355)\end{array}$ \\
\hline Economic freedom & & & & $\begin{array}{l}4.113 \\
(13.960)\end{array}$ & & \\
\hline Political freedom & & & & & $\begin{array}{l}0.028 \\
(5.325)\end{array}$ & \\
\hline
\end{tabular}


Table 5 (continued)

\begin{tabular}{|c|c|c|c|c|c|c|}
\hline & Model 1 & Model 2 & Model 3 & Model 4 & Model 5 & Model 6 \\
\hline Social freedom & & & & & & $\begin{array}{l}4.292 \\
(8.091)\end{array}$ \\
\hline \multicolumn{7}{|l|}{ Independent variable } \\
\hline Age & & $\begin{array}{l}-0.095 * * * \\
(0.029)\end{array}$ & $\begin{array}{l}-0.088 * * * \\
(0.030)\end{array}$ & $\begin{array}{l}-0.106^{* * *} \\
(0.031)\end{array}$ & $\begin{array}{l}-0.103 * * * \\
(0.031)\end{array}$ & $\begin{array}{l}-0.105^{* * * *} \\
(0.031)\end{array}$ \\
\hline $\operatorname{Age}^{2}$ & & & $\begin{array}{l}0.006 * * * \\
(0.002)\end{array}$ & $\begin{array}{l}0.007 * * * \\
(0.002)\end{array}$ & $\begin{array}{l}0.006 * * * \\
(0.002)\end{array}$ & $\begin{array}{l}0.006^{* * * *} \\
(0.002)\end{array}$ \\
\hline \multicolumn{7}{|l|}{ Cross-level effects } \\
\hline Age $\times$ Economic freedom & & & & $\begin{array}{l}-0.573 * \\
(0.311)\end{array}$ & & \\
\hline $\operatorname{Age}^{2} \times$ Economic freedom & & & & $\begin{array}{l}0.049 * * * \\
(0.014)\end{array}$ & & \\
\hline Age $\times$ Political freedom & & & & & $\begin{array}{l}-0.027 \\
(0.081)\end{array}$ & \\
\hline Age $^{2} \times$ Political freedom & & & & & $\begin{array}{l}0.016^{* * * *} \\
(0.005)\end{array}$ & \\
\hline Age $\times$ Social freedom & & & & & & $\begin{array}{l}0.011 \\
(0.114)\end{array}$ \\
\hline $\operatorname{Age}^{2} \times$ Social freedom & & & & & & $\begin{array}{l}0.026 * * * \\
(0.006)\end{array}$ \\
\hline Intraclass coefficient & 0.109 & 0.111 & 0.111 & 0.110 & 0.111 & 0.109 \\
\hline Individual-level variance & $571.4 * * *$ & $570.3 * * *$ & $569.6 * * *$ & $567.3 * * *$ & $567.3 * * *$ & $567.2 * * *$ \\
\hline Country-level variance & $69.97 * * *$ & $70.85 * * *$ & $71.35 * * *$ & $70.31 * * *$ & $70.51 * * *$ & $69.34 * * *$ \\
\hline AIC & $141,158.5$ & $141,132.4$ & $141,117.1$ & $141,090.6$ & $141,095.8$ & $141,092.4$ \\
\hline Log likelihood & $-70,559.3$ & $-70,545.2$ & $-70,536.6$ & $-70,519.3$ & $-70,521.9$ & $-70,520.2$ \\
\hline
\end{tabular}

$* p<0.1 ; * * p<0.05 ; * * *<<0.01$. Dependent variable: Social value creation. Standard errors are in parentheses. Mean-centered variables were used for independent and moderating variables. The sample includes 45 countries $(N=15,339)$

Fig. 3 Entrepreneur's age and social value creation goals

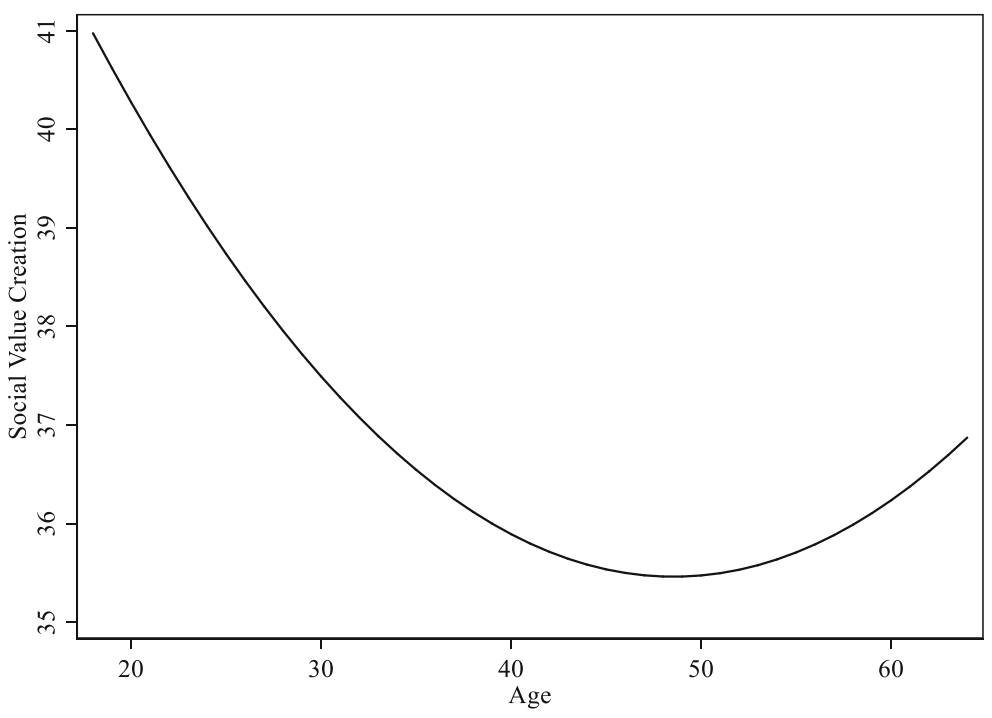


Fig. 4 Entrepreneur's age and social value creation goals: The moderating effect of economic freedom

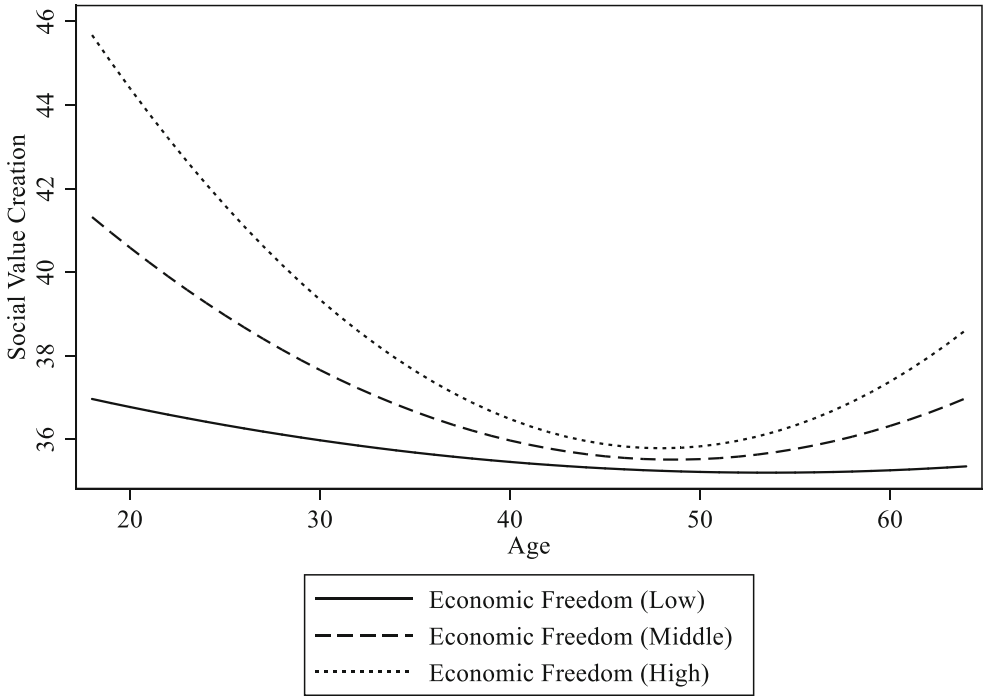

generation $X$ entrepreneurs (those individuals born 1965 and 1982). To further disentangle cohort effects from age effects in our data, we re-estimated our models controlling for cohort effects. Controlling for such effects did not reveal different patterns of results; all coefficients were of similar magnitude and pointed in the same direction as our model based on the total sample (see results in Table 6). We are therefore confident that the effects of entrepreneurs' age are not cohort effects.

Second, we tested whether the inclusion of institutional quality still persists across the age distribution. ${ }^{2}$ We thus performed quantile regression and see how institutional quality behaves in each percentile. Results displayed in Table 7 show that the hypothesized effects remains qualitatively stable across percentiles, suggesting that the interactions are not distorting our main results.

Third, we re-ran our analysis and excluded with Spain, the UK, and China those countries with larger sampling sizes. The results, which are available upon request, are entirely in accordance with our initial findings.

Moreover, we ran an additional set of analyses to test the robustness of our curvilinear relationship (see Haans et al. 2016). All results are available upon request. First, we conduct a Wald test to evaluate the joint significance of age and age squared. The results indicate that the joint effect of direct and squared terms of age is significant for

\footnotetext{
${ }^{2}$ We thank an anonymous reviewer for this suggestion.
}

entrepreneurs' social value creation [Wald chi-square = $20.27 ; p=0.000]$. Second, we test to determine whether age's effect on social value creation decreases at low values of age, and increases at high values of age. Our results confirm a U-shaped relationship between age and social value creation, as the slopes are negative and significant at lower values of age (applies for the age years 18 to 43 ) and positive and significant at high values of age (applies for the age years 57 to 64). We also compared the AIC fits of a quadratic and a linear model, and found that the quadratic model has a better fit. We also run a Sasabuchi's test (1980) to test for the presence of a U-shaped relationship using a country fixed-effects specification of Model 3. The result confirms the presence of a U-shaped relationship $(t$ value $=$ $2.35 ; p<0.01)$. Third, we follow Lind and Mehlum (2010) in using the Fieller approach to estimate confidence intervals for the extreme lower and upper bounds of age ( $95 \%$ interval for an extreme point): the interval ranges from 41.74 to 55.36 years, with an extreme point of 48.55 years. Fourth, we include all entrepreneurs above 64 years of age. We find very similar results, with the exception that the U-shaped relationship between age and social value creation becomes even stronger and more profound since entrepreneurs aged above 64 years report even higher levels of social value creation. Finally, we test the robustness of our U-shaped age effect by considering the stage of entrepreneurial activity, i.e., when controlling for nascent entrepreneurship - that is, all entrepreneurs who intend to start-up an own business, but have not already done so. The result is in line 
Fig. 5 Entrepreneur's age and social value creation goals: The moderating effect of political freedom

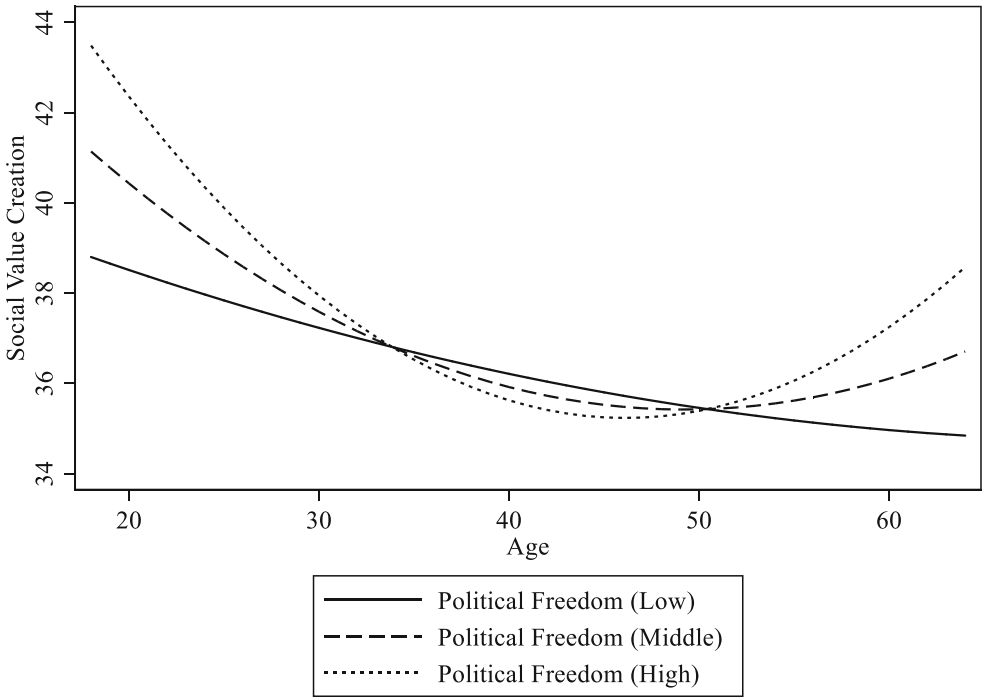

with the one reported in Model 3 of Table 5, with the only difference that the coefficient of the linear term is now significant at the $10 \%$ level, whereas the coefficient of the squared term is now significant at the $5 \%$ level.

\subsection{Auxiliary analysis}

While in our paper we focus on the role of formal institution as moderators of the age-value creation goals relationship, in this auxiliary analysis, we investigate whether informal institutions also play a role. While this conjecture goes beyond our theorizing, it is worth noting that previous research highlights that institutional freedoms, socioeconomic development, and individualist and postmaterialist cultures are key components of a "syndrome" of modernization in which economic, socio-cultural, and political trends are generally uniformly and predictably linked (Inglehart and Welzel 2005; Welzel 2013).

In line with this reasoning, we test whether the human development index, postmaterialism, and Hofstede's cultural value dimensions of individualism and power distance also moderate the relationship between entrepreneurs' age and social value creation. For completeness, we also included Hofstede's two other dimensions: uncertainty avoidance and masculinity. Table 8 results show that human development - which is a combined measure integrating people's (1) health, (2)
Fig. 6 Entrepreneur's age and social value creation goals: The moderating effect of social freedom

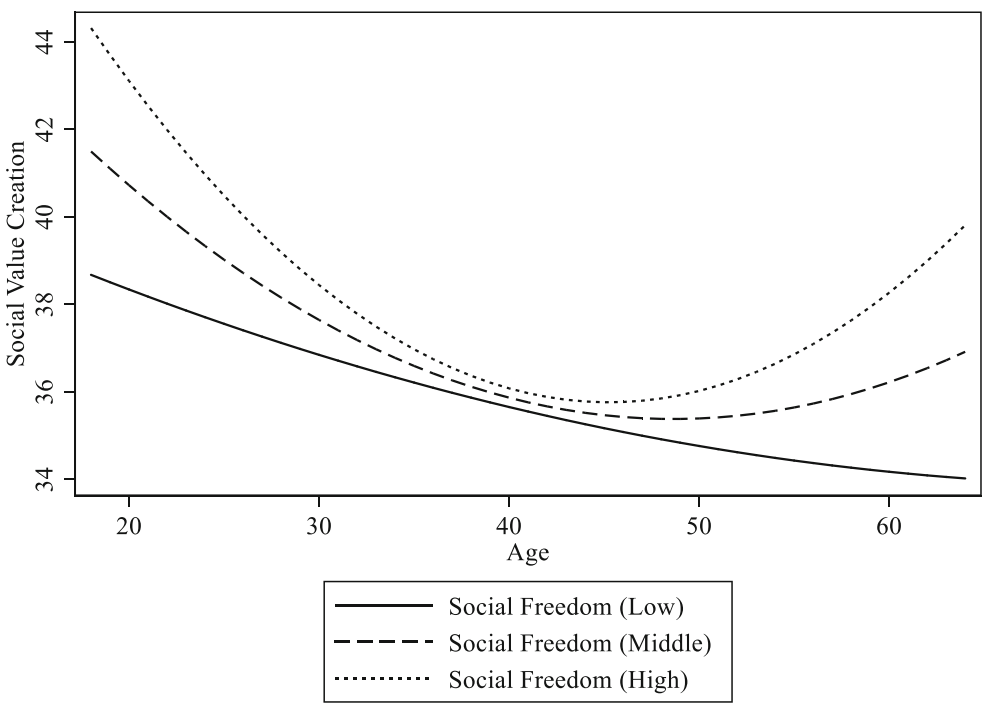


Table 6 Robustness check results

\begin{tabular}{|c|c|c|c|c|c|}
\hline & Model 7 & Model 8 & Model 9 & Model 10 & Model 11 \\
\hline Constant & $\begin{array}{l}28.240 \text { *** } \\
(5.041)\end{array}$ & $\begin{array}{l}27.350 * * * \\
(5.094)\end{array}$ & $\begin{array}{l}27.750 * * * \\
(4.804)\end{array}$ & $\begin{array}{l}27.830 \text { *** } \\
(5.549)\end{array}$ & $\begin{array}{l}28.360 \text { *** } \\
(5.439)\end{array}$ \\
\hline Individual-level controls & Yes & Yes & Yes & Yes & Yes \\
\hline Cohort & \multicolumn{5}{|c|}{ Reference $=$ Baby boomers } \\
\hline Generation X & $\begin{array}{l}-1.346^{* *} \\
(0.607)\end{array}$ & $\begin{array}{l}-1.113^{*} \\
(0.610)\end{array}$ & $\begin{array}{l}-1.209^{* *} \\
(0.600)\end{array}$ & $\begin{array}{l}-1.216^{* *} \\
(0.585)\end{array}$ & $\begin{array}{l}-1.226^{* *} \\
(0.590)\end{array}$ \\
\hline Millennials & $\begin{array}{l}0.222 \\
(1.338)\end{array}$ & $\begin{array}{l}-1.277 \\
(1.462)\end{array}$ & $\begin{array}{l}-0.975 \\
(1.450)\end{array}$ & $\begin{array}{l}-1.030 \\
(1.458)\end{array}$ & $\begin{array}{l}-0.984 \\
(1.456)\end{array}$ \\
\hline Country-level controls & Yes & Yes & Yes & Yes & Yes \\
\hline Economic freedom & & & $\begin{array}{l}3.774 \\
(13.960)\end{array}$ & & \\
\hline Political freedom & & & & $\begin{array}{l}-0.073 \\
(5.300)\end{array}$ & \\
\hline Social freedom & & & & & $\begin{array}{l}4.083 \\
(8.064)\end{array}$ \\
\hline \multicolumn{6}{|l|}{ Independent variable } \\
\hline Age & $\begin{array}{l}-0.111^{* *} \\
(0.050)\end{array}$ & $\begin{array}{l}-0.129 * * \\
(0.0530)\end{array}$ & $\begin{array}{l}-0.145^{* * * *} \\
(0.055)\end{array}$ & $\begin{array}{l}-0.143 * * * \\
(0.054)\end{array}$ & $\begin{array}{l}-0.144 * * * \\
(0.054)\end{array}$ \\
\hline $\mathrm{Age}^{2}$ & & $\begin{array}{l}0.005 * * \\
(0.002)\end{array}$ & $\begin{array}{l}0.006^{* * *} \\
(0.002)\end{array}$ & $\begin{array}{l}0.005^{* *} \\
(0.002)\end{array}$ & $\begin{array}{l}0.005^{* *} \\
(0.002)\end{array}$ \\
\hline \multicolumn{6}{|l|}{ Cross-level effects } \\
\hline Age $\times$ Economic freedom & & & $\begin{array}{l}-0.575^{*} \\
(0.310)\end{array}$ & & \\
\hline $\mathrm{Age}^{2} \times$ Economic freedom & & & $\begin{array}{l}0.051^{* * * *} \\
(0.013)\end{array}$ & & \\
\hline Age $\times$ Political freedom & & & & $\begin{array}{l}-0.027 \\
(0.080)\end{array}$ & \\
\hline $\mathrm{Age}^{2} \times$ Political freedom & & & & $\begin{array}{l}0.016^{* * * *} \\
(0.005)\end{array}$ & \\
\hline Age $\times$ Social freedom & & & & & $\begin{array}{l}0.007 \\
(0.112)\end{array}$ \\
\hline $\mathrm{Age}^{2} \times$ Social freedom & & & & & $\begin{array}{l}0.027 * * * \\
(0.006)\end{array}$ \\
\hline Intraclass coefficient & 0.111 & 0.111 & 0.110 & 0.110 & 0.109 \\
\hline Individual-level variance & $569.8^{* * *}$ & $569.6^{* * * *}$ & $567.2 * * *$ & $567.2 * * *$ & $567.1 * * *$ \\
\hline Country-level variance & $71.10 * * *$ & $71.23 * * *$ & $70.16^{* * *}$ & $70.35 * * *$ & $69.20 * * *$ \\
\hline AIC & $141,124.3$ & $141,119.2$ & $141,091.9$ & $141,097.2$ & $141,093.6$ \\
\hline Log likelihood & $-70,539.2$ & $-70,535.6$ & $-70,517.9$ & $-70,520.6$ & $-70,518.8$ \\
\hline
\end{tabular}

${ }^{*} p<0.1 ; * * p<0.05 ; * * * p<0.01$. Dependent variable: Social value creation. Standard errors are in parentheses. Mean-centered variables were used for independent and moderating variables. All regressions control for individual and country-level variables as introduced in Table 5 above. The sample includes 45 countries $(N=15,339)$. Baby boomers (born 1945-1964), Generation X (born 1965-1982), Millennials (born 1983-1996)

education, and (3) standard of living - steepens the Ushaped relationship between entrepreneurs' age and social value creation. Moreover, postmaterialism strengthens the positive relationship between age squared and social value creation (but not the direct age effect on social value creation), whereas individualism and masculinity strengthen the direct effect of age on social value creation (but not the association of age squared and social value creation). Also, we find evidence that power distance flattens the U-shaped 
Table 7 Quantile regression results

\begin{tabular}{|c|c|c|c|c|c|c|c|c|c|}
\hline & \multicolumn{9}{|l|}{ Quantiles } \\
\hline & $25 \%$ & $50 \%$ & $75 \%$ & $25 \%$ & $50 \%$ & $75 \%$ & $25 \%$ & $50 \%$ & $75 \%$ \\
\hline \multicolumn{10}{|l|}{ Independent variable } \\
\hline Age & $\begin{array}{l}-0.105 * * * \\
(-4.700)\end{array}$ & $\begin{array}{l}-0.113 * * * \\
(-3.520)\end{array}$ & $\begin{array}{l}-0.063 * * \\
(-2.420)\end{array}$ & $\begin{array}{l}-0.109 * * * \\
(-4.06)\end{array}$ & $\begin{array}{l}-0.112 * * * \\
(-3.09)\end{array}$ & $\begin{array}{l}-0.061^{* *} \\
(-2.16)\end{array}$ & $\begin{array}{l}-0.088 * * * \\
(-3.32)\end{array}$ & $\begin{array}{l}-0.113 * * * \\
(-2.99)\end{array}$ & $\begin{array}{l}-0.069 * * \\
(-2.53)\end{array}$ \\
\hline $\mathrm{Age}^{2}$ & $\begin{array}{l}0.006 * * * \\
(3.530)\end{array}$ & $\begin{array}{l}0.00329 \\
(1.33)\end{array}$ & $\begin{array}{l}0.004 * \\
(1.85)\end{array}$ & $\begin{array}{l}0.006^{* * * *} \\
(3.29)\end{array}$ & $\begin{array}{l}0.005 * \\
(1.70)\end{array}$ & $\begin{array}{l}0.003 \\
(1.42)\end{array}$ & $\begin{array}{l}0.005^{* *} \\
(2.57)\end{array}$ & $\begin{array}{l}0.007 * * \\
(2.20)\end{array}$ & $\begin{array}{l}0.005 * * \\
(2.27)\end{array}$ \\
\hline \multicolumn{10}{|l|}{ Cross-level effects } \\
\hline $\begin{array}{r}\text { Economic } \\
\text { freedom }\end{array}$ & $\begin{array}{l}3.462 \\
(0.730)\end{array}$ & $\begin{array}{l}1.410 \\
(0.220)\end{array}$ & $\begin{array}{l}-6.706 \\
(-1.630)\end{array}$ & & & & & & \\
\hline$\times$ Age & $\begin{array}{l}-0.260 \\
(-1.190)\end{array}$ & $\begin{array}{l}-0.429 \\
(-1.420)\end{array}$ & $\begin{array}{l}-0.615^{* *} \\
(-2.280)\end{array}$ & & & & & & \\
\hline$\times \mathrm{Age}^{2}$ & $\begin{array}{l}0.043 * * \\
(2.410)\end{array}$ & $\begin{array}{l}0.080 * * * \\
(3.430)\end{array}$ & $\begin{array}{l}0.069 * * * \\
(3.080)\end{array}$ & & & & & & \\
\hline Political freedom & & & & $\begin{array}{l}-11.720 * * * \\
(-10.950)\end{array}$ & $\begin{array}{l}-2.891 * \\
(-1.820)\end{array}$ & $\begin{array}{l}-2.455 * * * \\
(-2.710)\end{array}$ & & & \\
\hline$\times$ Age & & & & $\begin{array}{l}-0.095 \\
(-1.570)\end{array}$ & $\begin{array}{l}-0.083 \\
(-1.100)\end{array}$ & $\begin{array}{l}-0.062 \\
(-0.740)\end{array}$ & & & \\
\hline$\times \mathrm{Age}^{2}$ & & & & $\begin{array}{l}0.010 * * \\
(2.130)\end{array}$ & $\begin{array}{l}0.023 * * * \\
(3.570)\end{array}$ & $\begin{array}{l}0.027 * * * \\
(3.720)\end{array}$ & & & \\
\hline Social freedom & & & & & & & $\begin{array}{l}-22.100 * * * \\
(-14.030)\end{array}$ & $\begin{array}{l}-5.350 * * \\
(-2.370)\end{array}$ & $\begin{array}{l}-2.607 * \\
(-1.780)\end{array}$ \\
\hline$\times$ Age & & & & & & & $\begin{array}{l}-0.0574 \\
(-0.560)\end{array}$ & $\begin{array}{l}-0.0470 \\
(-0.490)\end{array}$ & $\begin{array}{l}-0.187 * * \\
(-2.160)\end{array}$ \\
\hline$\times \mathrm{Age}^{2}$ & & & & & & & $\begin{array}{l}0.0189 * * * \\
(2.940)\end{array}$ & $\begin{array}{l}0.0415^{* * * *} \\
(4.930)\end{array}$ & $\begin{array}{l}0.0524 * * * \\
(7.790)\end{array}$ \\
\hline
\end{tabular}

$* p<0.1 ; * *<0.05 ; * * * p<0.01$. Dependent variable: Social value creation. Quantile regressions for the 25th, 50th, and 75th percentiles. Standard errors are in parentheses. Mean-centered variables were used for independent and moderating variables. All regressions control for individual and country-level variables as introduced in Table 5 above

relationship. Altogether, these findings indicate that all variables that are closely intertwined with modernization also moderate the relationship between entrepreneurs' age and social value creation.

\section{Discussion}

Entrepreneurship research has long focused on the relationship between individuals' age and their entrepreneurial activity. Existing literature mainly explores age differences in "conventional" entrepreneurial motivation or behavior (Minola et al. 2016), or examines different age groups separately, such as third-age individuals (Kautonen et al. 2011), young entrepreneurs
(Minola et al. 2014), or individuals nearing retirement (Heim 2015). While these studies significantly advanced our understanding of the role of individuals' age on entrepreneurship, they present three important limitations. First, prior studies often build "on the traditional depiction of mainstream entrepreneurship as an individualistic and profit-maximizing endeavor" (Hechavarría et al. 2012, p. 137); yet, recent research provides substantial evidence that entrepreneurs pursue multiple business objectives, seeking to not only make profits but often also contribute to societal well-being and a healthy environment (e.g., Bacq et al. 2016; Cohen et al. 2008; Hörisch et al. 2017). Second, developmental theories such as lifespan psychology suggest that people's intentions, goals, and motives differ depending on one's stage 
Table 8 Auxiliary analysis results

\begin{tabular}{|c|c|c|c|}
\hline & Model 12 & Model 13 & Model 1 \\
\hline Constant & $\begin{array}{l}26.520 * * * \\
(5.018)\end{array}$ & $\begin{array}{l}24.200^{* * *} \\
(5.848)\end{array}$ & $\begin{array}{l}25.360^{*} \\
(6.719)\end{array}$ \\
\hline Individual-level controls & Yes & Yes & Yes \\
\hline Country-level controls & Yes & Yes & Yes \\
\hline \multicolumn{4}{|l|}{ Independent variable } \\
\hline Age & $\begin{array}{l}-0.105^{* * *} \\
(0.031)\end{array}$ & $\begin{array}{l}-0.112 * * * \\
(0.033)\end{array}$ & $\begin{array}{l}-0.085 \\
(0.036)\end{array}$ \\
\hline $\mathrm{Age}^{2}$ & $\begin{array}{l}0.007 * * * \\
(0.002)\end{array}$ & $\begin{array}{l}0.004 * * * \\
(0.002)\end{array}$ & $\begin{array}{l}0.008 * * \\
(0.002)\end{array}$ \\
\hline \multicolumn{4}{|l|}{ Cross-level effects } \\
\hline HDI & $\begin{array}{l}8.066 \\
(22.780)\end{array}$ & & \\
\hline$\times$ Age & $\begin{array}{l}-0.105^{* * *} \\
(0.031)\end{array}$ & & \\
\hline$\times \mathrm{Age}^{2}$ & $\begin{array}{l}0.007 * * * \\
(0.002)\end{array}$ & & \\
\hline Postmaterialism values & & $\begin{array}{l}2.001 \\
(9.380)\end{array}$ & \\
\hline$\times$ Age & & $\begin{array}{l}-0.032 \\
(0.151)\end{array}$ & \\
\hline$\times \mathrm{Age}^{2}$ & & $\begin{array}{l}0.022 * * * \\
(0.006)\end{array}$ & \\
\hline Uncertainty avoidance & & & $\begin{array}{l}-0.052 \\
(0.055)\end{array}$ \\
\hline$\times$ Age & & & $\begin{array}{l}0.002 \\
(0.001)\end{array}$ \\
\hline$\times \mathrm{Age}^{2}$ & & & $\begin{array}{l}0.000 \\
(0.000)\end{array}$ \\
\hline
\end{tabular}

Power distance

0.093

(0.102)

$0.003 * *$

(0.001)

-0.000 **

(0.000)

Individualism

$-0.066$

(0.118)

$\times$ Age

$-0.004 * * *$

0.000

(0.000)

$\times \mathrm{Age}^{2}$

0.000

Masculinity

$-0.068$

(0.105)

$-0.004 * *$

(0.002)

$-0.000$ 
Table 8 (continued)

\begin{tabular}{lllllll}
\hline & Model 12 & Model 13 & Model 14 & Model 15 & Model 16 & Model 17 \\
\hline & & & & $0.000)$ \\
Observations & 15,339 & 13,234 & 12,797 & 12,797 & 12,797 & 12,797 \\
Countries & 45 & 35 & 36 & 36 & 36 & 36 \\
Intraclass coefficient & 0.109 & 0.118 & 0.120 & 0.120 & 0.120 & 0.119 \\
Individual-level variance & $567.1 * * *$ & $562.1 * * *$ & $569.3 * * *$ & $569.3 * * *$ & $569.5 * * *$ & $569.4 * * *$ \\
Country-level variance & $69.66^{* * *}$ & $75.50 * * *$ & $77.78 * * *$ & $77.41 * * *$ & $77.50 * * *$ & $77.18 * * *$ \\
AIC & $141,090.0$ & $121,270.2$ & $117,660.4$ & $117,658.9$ & $117,655.3$ & $117,658.6$ \\
Log likelihood & $-70,519.0$ & $-60,609.1$ & $-58,804.2$ & $-58,803.5$ & $-58,801.7$ & $-58,803.3$ \\
\hline
\end{tabular}

$* p<0.1 ; * *<<0.05 ; * * * p<0.01$. Dependent variable: Social value creation. Standard errors are in parentheses. Mean-centered variables were used for independent and moderating variables. HDI human development index

in his/her lifecycle and, consequently, shift individuals' goal orientations (Baltes et al. 2006; Ebner et al. 2006). While prior studies build on this perspective to assess what may trigger individuals' entrepreneurial motivation (Minola et al. 2016) or new venture growth (Gielnik et al. 2012), we know little about the relationship between entrepreneurs' age and the value creation goals they seek through their businesses. Third, the successful realization of intentions, goals, and motives is "sensitive" to context (Athayde 2009; Obschonka and Silbereisen 2012; Stephan et al. 2015). However, previous research on the relationship between age and entrepreneurship either neglected this contextual perspective (Carsrud and Brännback 2011; Gielnik et al. 2012; Obschonka and Silbereisen 2012) or focused on cultural features (Minola et al. 2016). Consequently, a focus on institutional characteristics in the age-value creation linkage provides a more complete understanding of the conditions under which entrepreneurs may better realize their value creation goals.

Our study argues for age-dependent inter-individual differences in value creation goals by entrepreneurs. Even if the cross-sectional dataset used in this study does not allow to draw a final conclusion as to whether entrepreneurs change their value creation goals over their lifespan, our results provide a first evidence that entrepreneurs' goals differ depending on their age and supposedly position in the lifespan. In that, entrepreneurs in their middle age are relatively more economically and less socially oriented, whereas both younger and older entrepreneurs express higher socially oriented goals through their businesses. We also find that cross-sectional age differences in entrepreneurs' goals in doing business vary depending on the characteristics of the formal environment where these entrepreneurs are embedded. Compared to countries with low institutional quality, countries with high institutional quality allow middle age entrepreneurs to follow their innate affinity towards personal wealth and prosperity, whereas younger and older entrepreneurs to create higher social value. More specifically, our analysis reveals that economic freedom steepens the U-shaped relationship between an entrepreneur's age and his/her social value creation. Evidently, well-functioning economic institutions seem to provide a fruitful environment for entrepreneurs to pursue their goals. Conversely, environments with low-quality institutions provide more restrictive conditions that inhibit individual decision making, and thus make it more difficult for entrepreneurs to pursue their individual preferences regarding value creation when structuring and running their venture, i.e., economic value creation in middle adulthood, and social value creation in young and old adulthood. As our figures demonstrate, the curvilinear relationship is flatter in weak institutional settings, indicating that young, middle, and old entrepreneurs may possess a more equal blend of both social and economic value creation goals, compared with entrepreneurs in stronger institutional settings where the U-shaped relationship between entrepreneurs' age and social value creation is steeper. In settings where political and social freedoms are weak, we find a linear negative relationship between entrepreneurs' age and social value creation goals, implying that entrepreneurs are more commercially oriented with increasing age. This is understandable given the fact that the conditions under which entrepreneurs operate are much more disadvantageous, and it might 
be the case that responsibilities increase much more with age in tougher environments. In sum, economic, political, and social freedoms influence entrepreneurial value creation and corresponding economic outcomes since they affect how entrepreneurs may perceive costs and benefits depending on their age (Boettke and Coyne 2009). Our results thus raise attention to institutional mechanisms that shape individuals' entrepreneurial activities at different life stages and in different countries.

Interestingly, the results from our auxiliary analysis also suggest that informal institutions also influence the relationship between entrepreneurs' age and their social value creation goals. This seems logical given the fact that high-quality institutions, which guarantee people's economic, political, and social freedoms, are typically surrounded by empowering existential and cultural conditions (Inglehart and Welzel 2005; Welzel 2013). As Welzel (2013) points out in "Freedom Rising," human empowerment advances on a three-lane trajectory consisting of (1) a socioeconomic development in form of incomes and education (which generate capabilities to exercise universal freedoms), (2) an emancipative culture that prioritizes autonomy, choice, and selfexpression (which embody motivations to exercise universal freedoms), and (3) civic entitlements (which establish guarantees to exercise universal freedoms). Based on large cross-national samples, Welzel argues and shows empirically that socioeconomic development culminates into an emancipative culture, which, in turn, motivates people to be involved in social movement activities to introduce, defend, and extend civic entitlements in form of economic, political, and social freedoms (Welzel 2013). Consequently, as socioeconomic, cultural, and institutional conditions are usually interlinked, we find also significant moderating effects of socioeconomic and cultural factors.

\subsection{Theoretical contributions}

Our study provides three main contributions to theory. First, we are among the first to theoretically argue and empirically show cross-sectional age differences in social value creation goals of entrepreneurs. Existing studies dealing with individuals' age and entrepreneurship typically focus on "conventional" entrepreneurship by showing that an individual's desire to start a venture increases up to middle age and decreases thereafter (e.g., Funken and Gielnik 2015; Lévesque and Minniti 2006;
Parker 2009). By integrating the age-entrepreneurship debate with the multi-dimensionality of value creation goals of entrepreneurs and their businesses, we theorize and show that a U-shaped relationship exists between entrepreneurs' age and their perceptions to create social value goals with their businesses. As such, this study fundamentally refines our understanding of the extant theory by challenging the well-established inverted Ushaped relationship between individuals' age and entrepreneurship.

Second, our study shows that entrepreneurs' creation of social value through their organizations changes across different age groups. We respond to both calls to broaden the scope of entrepreneurial value creation (Amit et al. 2001; Cohen et al. 2008; Hechavarría et al. 2017) and to apply a developmental perspective to entrepreneurship research (Carsrud and Brännback 2011; Gielnik et al. 2012; Lévesque and Minniti 2006; Minola et al. 2016; Obschonka and Silbereisen 2012). Focusing solely on financial-related goals and outcomes in entrepreneurship leads to an incomplete understanding of entrepreneurial behavior in individuals (Zahra and Wright 2011). By broadening the scope to relevant dependent variables such as entrepreneurs' social value creation goals and by taking a developmental perspective into account, this study advances and extends the current discourse on (multiple) value creation goals in entrepreneurship (e.g., Brieger et al. 2019; Hechavarría et al. 2017; Hörisch et al. 2017, 2019).

Third, we contribute to the scholarly debate on institutional theory in entrepreneurship research (Bruton et al. 2010; De Clercq et al. 2013) by showing that formal institutions influence the relationship between entrepreneurs' age and their value creation goals. Our multilevel approach predicts age-related differences in the extent to which entrepreneurs create social value with their businesses. Drawing on lifespan developmental psychology and institutional theory, we argue and empirically show that the quality of formal institutions influences the relationship between entrepreneurs' age and their value creation goals. We show that a country's institutional quality is a key contingency that helps explaining entrepreneurs' value preferences. We also contribute to the debate around institutional theory and social value creation (Brieger et al. 2019; Hechavarría 2016) by introducing an age perspective to such debate. Previous research investigates the direct and indirect effects of formal and informal institutions on socially oriented entrepreneurial activity. By applying 
both lifespan developmental psychology and institutional theory to the field of entrepreneurship, we deliver a new profound understanding of how entrepreneurs' value creation preferences vary across different age groups as well as how entrepreneurs can be supported by their countries' institutions to achieve such preferences. Thus, we present new insights into the factors that relate to social (and economic) value creation in entrepreneurship across countries, thereby contributing to the ongoing debate in (social) entrepreneurship research (e.g., Dacin et al. 2010, 2011; Hoogendoorn 2016; Mair and Marti 2006, 2009; Zahra and Wright 2011).

Finally, with our auxiliary analyses, we provide empirical evidence that not only formal institutions but also socioeconomic development and culture influence the relationship between entrepreneurs' age and their value creation goals. Many studies have provided evidence of the key role that formal institutions play for social entrepreneurial activity. However, some authors such as Inglehart and Welzel (2005) have shown that societies with high-quality formal institutions tend to have a higher level of prosperity and an emancipated culture that give priority to autonomy, self-expression, and initiative at the same time. Consequently, if formal institutions influence social value creation, this should also apply to socioeconomic development and culture. Initial evidence for this conjecture was recently provided by Brieger et al. (2019) who point out that entrepreneurs create more social value with their ventures when they are not only empowered institutionally (e.g., institutions protect political, and social freedoms) but also existentially (e.g., having resources) and psychologically (e.g., culture gives priority to autonomy, equality, and participation). Our study supports the presence of a triad of economy, culture, and institutions by showing that all three components moderate the relationship between entrepreneurs' age and their social value creation goals in a predictable way. In view of these results, we can conclude that all those interacting components of modernization, such as (1) institutional freedoms in terms of economic, social, and political freedoms, (2) socioeconomic development in terms of higher levels of incomes, health and education, and (3) an emancipative culture that prioritizes autonomy and independence and emphasizes self-expression and quality of life over economic and physical security play important moderating roles in the relationship between entrepreneurs' age and their social value creation goals.

\subsection{Policy and practical implications}

Our results offer important implications for policy and practice. Knowing the existence of cross-sectional age differences in entrepreneurs' value creation goals, policy makers should design age-group ${ }^{-}$specific policies to help entrepreneurs achieving their different goals. For instance, countries could implement entrepreneurship programs targeted at improving third-age entrepreneurs' understanding of how they can implement, integrate, and sustain societal goals in their businesses (e.g., Howorth et al. 2012). Moreover, policy makers must acknowledge that their countries' institutional quality is an important factor in the age-value creation linkage and that borrowing successful policies from countries with very diverse institutional settings to stimulate social value creation in entrepreneurs may not always be efficient. Instead, policy makers should create favorable and supportive institutional environments that allow entrepreneurs to follow their innate preferences. Moreover, policy makers may try to strengthen the abundance of empowering resources such as income and education. Previous research already documented that supportive existential conditions could stipulate social value creation (Brieger 2019; Hoogendoorn 2016). In line with this research, our auxiliary analysis reveals that higher levels of socioeconomic development may allow entrepreneurs to follow their innate preferences. We also suggest that the abundance of financial security and provision of social and financial support could also motivate entrepreneurs in their middle ages to create more social value. Public sector expenditure has been found to be positively linked with a country's level of social entrepreneurial activity (Hoogendoorn 2016).

Our results are also relevant for potential entrepreneurs. Empirical evidence shows that structural changes in the economy of developed countries - including declining traditional labor markets, the impact of new technologies, and youth unemployment - are "forcing" many young and older individuals to consider selfemployment over traditional employment (e.g., Kautonen et al. 2014; Minola et al. 2016). To fulfill their often non-financial motives and goals, younger and older individuals should acknowledge the existence of an "alternative" view of entrepreneurshipthat challanges entrepreneurs to solve environmental and social challenges and government failures such as inequality, poverty, and pollution. 


\subsection{Limitations and future research directions}

Our study is not without limitations, which present fertile ground for future research. First, while the GEM data enables multivariate analyses which increases our understanding of how the variables are interrelated, its cross-sectional nature, however, can only allow us to provide information about age group differences or inter-individual differences rather than providing information about intra-individual age change. Although cross-sectional designs like ours are very common in lifespan developmental psychology studies (see Schmidt and Teti 2005 and Whitbourne 2019 for two reviews), longitudinal studies would be preferable to provide the ultimate evidence on the effect of entrepreneurs' age changes on social value creation across time. More importantly, our cross-sectional design does not fully allow us to determine conclusively whether the Ushaped relationship between entrepreneurs' age and social value creation are due to true aging effects, cohort effects, or period effects (Mackenzie et al. 2018). Despite these limitations, we still believe that what we observe are age effects rather than cohort effects for two reasons. First, the U-shaped relationship is still present when controlling for cohort effects (see Table 6). Despite our belief that aging effects, rather than cohort effects, drive our results, further research is needed to test relationships using different study designs; yet, we acknowledge the challenges associated with the implementation of a longitudinal design that enables to follow individuals throughout their whole lifespan as well as the limitations of longitudinal designs in lifespan developmental psychology studies (see Schmidt and Teti 2005).

Second, our study captures entrepreneurs' perceived value creation rather than actual value creation. Future research could explore whether more objective measures of such variable would yield to similar results. An additional limitation refers to an individual's understanding of social and economic value creation. While one may think of extreme cases of commercial entrepreneurship where founders solely aim to achieve financial provision and asset generation on the one side or pursue purely philanthropic business models on the other side, this is mostly not the case. Even at these extreme points, there are still aspects of both. That is, social value creation also relies on economic realities just as economic-oriented businesses generate social value (Austin et al. 2006). In fact, social and economic value creation are not orthogonal, but rather dimensional, concepts, which describe entrepreneurs' activities on a continuum ranging from purely social to purely commercial.

Third, as mentioned before, according to lifespan psychology, individuals' goals and motives are not always linked to age, but rather to an individual's perception of his/her time remaining; as proposed by Carstensen (2006, p. 1913), "because goal-directed behavior relies inherently on perceived future time, the perception of time is inextricably linked to goal selection and goal pursuit." When time is perceived as finite, e.g., due to major life events such as illnesses, war, or geographical relocation, associated opportunities are also affected, potentially causing personal goal shifts (Carstensen 2006; Lang and Carstensen 2002). Previous research indicates that when manipulating or controlling for people's time perspective, there are diminished age differences regarding motivations (Carstensen 2006; Gielnik et al. 2012; Lang and Carstensen 2002; Zacher and Frese 2009). Thus, future research should control for individuals' subjective sense of their perceived time constraints.

Fourth, our focus on formal institutional quality, measured by a country's level of economic, political, and social freedom is just one plausible moderating mechanism in the age-social value creation relationship. In line with our auxiliary analysis, future research should investigate if and how additional informal institutions such as a country's trust level or social identity influence the relationship between age and social value creation (e.g., Brieger 2019; Pathak and Muralidharan 2016; Stephan et al. 2015). With respect to recent insights concerning the interplay of gender and informal institutions (Brieger et al. 2019; Hechavarría et al. 2017), it would also be interesting to examine age patterns in the relationships between gender, culture, and value creation goals.

Finally, the high correlation between formal institutional quality and economic development stage could lead to the assumption that not primarily wellfunctioning institutions, but rather the abundance of material security, moderates the age-social value creation linkage. If material security is certain, entrepreneurs may prioritize values that are more prevalent in the respective life phase. We find that GDP per capita does not reinforce the negative linkage between age and social value creation goals, but it moderates the positive association of age squared and social value creation 
goals $(p<0.05)$. However, the effect becomes insignificant once we include economic, political or social freedom into the model, respectively. This confirms the importance of institutional quality for the relationship between age and social value creation. However, future research could focus on the role of country- and individual-level incomes and wealth for the relationship between age and social value creation to bring more clarity to this matter.

Acknowledgements The authors would like to thank the editorial team of Adam Lederer at the Small Business Economics Journal for their excellent support. Our thanks also go to the anonymous reviewers for their very helpful comments, criticism, and suggestions.

Open Access This article is licensed under a Creative Commons Attribution 4.0 International License, which permits use, sharing, adaptation, distribution and reproduction in any medium or format, as long as you give appropriate credit to the original author(s) and the source, provide a link to the Creative Commons licence, and indicate if changes were made. The images or other third party material in this article are included in the article's Creative Commons licence, unless indicated otherwise in a credit line to the material. If material is not included in the article's Creative Commons licence and your intended use is not permitted by statutory regulation or exceeds the permitted use, you will need to obtain permission directly from the copyright holder. To view a copy of this licence, visit http://creativecommons.org/licenses/by/4.0/.

\section{References}

Achenbach, T. M. (1978). Research in developmental psychology: concepts, strategies, methods. New York: Free Press.

Acs, Z. J., Boardman, M. C., \& McNeely, C. L. (2013). The social value of productive entrepreneurship. Small Business Economics, 40(3), 785-796. https://doi.org/10.1007 /s11187-011-9396-6.

Aidis, R., Estrin, S., \& Mickiewicz, T. M. (2012). Size matters: entrepreneurial entry and government. Small Business Economics, 39(1), 119-139. https://doi.org/10.1007/s11187010-9299-y.

Allemand, M., Zimprich, D., \& Hertzog, C. (2007). Crosssectional age differences and longitudinal age changes of personality in middle adulthood and old age. Journal of Personality, 75(2), 323-358. https://doi.org/10.1111/j.14676494.2006.00441.x.

Amit, R., MacCrimmon, K. R., Zietsma, C., \& Oesch, J. M. (2001). Does money matter? Wealth attainment as the motive for initiating growth-oriented technology ventures. Journal of Business Venturing, 16(2), 119-143. https://doi. org/10.1016/S0883-9026(99)00044-0.

Athayde, R. (2009). Measuring enterprise potential in young people. Entrepreneurship Theory and Practice, 33(2), 481-500. https://doi.org/10.1111/j.1540-6520.2009.00300.x.
Austin, J., Stevenson, H., \& Wei-Skillern, J. (2006). Social and commercial entrepreneurship: same, different, or both? Entrepreneurship Theory and Practice, 30(1), 1-22. https://doi.org/10.1111/j.1540-6520.2006.00107.x.

Autio, E., Pathak, S., \& Wennberg, K. (2013). Consequences of cultural practices for entrepreneurial behaviors. Journal of International Business Studies, 44(4), 334-362. https://doi. org/10.1057/jibs.2013.15.

Bacq, S., Hartog, C., \& Hoogendoorn, B. (2016). Beyond the moral portrayal of social entrepreneurs: an empirical approach to who they are and what drives them. Journal of Business Ethics, 133(4), 703-718. https://doi.org/10.1007/s10551-014-2446-7.

Baltes, P. B. (1987). Theoretical propositions of life-span developmental psychology: on the dynamics between growth and decline. Developmental Psychology, 23(5), 611-626. https://doi.org/10.1037/0012-1649.23.5.611.

Baltes, P. B., Lindenberger, U., \& Staudinger, U. M. (2006). Life span theory in developmental psychology Handbook of child psychology: theoretical models of human development (Vol. 1, pp. 569-664). Hoboken.

Bergmann, H., \& Stephan, U. (2013). Moving on from nascent entrepreneurship: measuring cross-national differences in the transition to new business ownership. Small Business Economics, 41(4), 945-959. https://doi.org/10.1007 /s11187-012-9458-4.

Boettke, P. J., \& Coyne, C. J. (2009). Context matters: institutions and entrepreneurship. Foundations and Trends in Entrepreneurship, 5(3), 135-209. https://doi.org/10.1561 10300000018.

Bönte, W., Falck, O., \& Heblich, S. (2009). The impact of regional age structure on entrepreneurship. Economic Geography, 85(3), 269-287. https://doi.org/10.1111/j.1944-8287.2009.01032.x.

Bosma, N. (2013). The global entrepreneurship monitor (GEM) and its impact on entrepreneurship research. Foundations and Trends in Entrepreneurship, 9(2), 143-248. https://doi. org/10.1561/0300000033.

Bowen, H. P., \& De Clercq, D. (2008). Institutional context and the allocation of entrepreneurial effort. Journal of International Business Studies, 39(4), 747-767. https://doi. org/10.1057/palgrave.jibs.8400343.

Brickson, S. L. (2007). Organizational identity orientation: the genesis of the role of the firm and distinct forms of social value. Academy of Management Review, 32(3), 864-888. https://doi.org/10.5465/amr.2007.25275679.

Brieger, S. A. (2019). Social identity and environmental concern: the importance of contextual effects. Environment and Behavior, 51(7), 828-855. https://doi.org/10.1177 /0013916518756988.

Brieger, S. A., \& De Clercq, D. (2019). Entrepreneurs' individuallevel resources and social value creation goals: the moderating role of cultural context. International Journal of Entrepreneurial Behavior \& Research, 25(2), 193-216. https://doi.org/10.1108/IJEBR-12-2017-0503.

Brieger, S. A., Terjesen, S. A., Hechavarría, D. M., \& Welzel, C. (2019). Prosociality in business: a human empowerment framework. Journal of Business Ethics, 159(2), 361-380. https://doi.org/10.1007/s10551-018-4045-5.

Bruton, G. D., Ahlstrom, D., \& Li, H. L. (2010). Institutional theory and entrepreneurship: where are we now and where do we need to move in the future? Entrepreneurship Theory 
and Practice, 34(3), 421-440. https://doi.org/10.1111 jj.1540-6520.2010.00390.x.

Carsrud, A., \& Brännback, M. (2011). Entrepreneurial motivations: what do we still need to know? Journal of Small Business Management, 49(1), 9-26. https://doi.org/10.1111 j.1540-627X.2010.00312.x.

Carstensen, L. L. (1995). Evidence for a life-span theory of socioemotional selectivity. Current Directions in Psychological Science, 4(5), 151-156. https://doi. org/10.1111/1467-8721.ep11512261.

Carstensen, L. L. (2006). The influence of a sense of time on human development. Science, 312(5782), 1913-1915. https://doi.org/10.1126/science.1127488.

Carstensen, L. L., Isaacowitz, D. M., \& Charles, S. T. (1999). Taking time seriously: a theory of socioemotional selectivity. American Psychologist, 54(3), 165-181. https://doi. org/10.1037/0003-066X.54.3.165.

Clegg, A., \& Fifer, S. (2014). Senior self-employment and entrepreneurship - a PRIME perspective. Public Policy \& Aging Report, 24(4), 168-172. https://doi.org/10.1093 /ppar/pru042.

Cohen, B., Smith, B., \& Mitchell, R. (2008). Toward a sustainable conceptualization of dependent variables in entrepreneurship research. Business Strategy and the Environment, 17(2), 107-119. https://doi.org/10.1002/bse.505.

Curran, J., \& Blackburn, R. A. (2001). Older people and the enterprise society: age and self-employment propensities. Work, Employment and Society, 15(4), 889-902. https://doi. org/10.1177/095001701400438279.

Dacin, P. A., Dacin, M. T., \& Matear, M. (2010). Social entrepreneurship: why we don't need a new theory and how we move forward from here. Academy of Management Perspectives, 24(3), 37-57. https://doi.org/10.5465/amp.24.3.37.

Dacin, M. T., Dacin, P. A., \& Tracey, P. (2011). Social entrepreneurship: a critique and future directions. Organization Science, 22(5), 1203-1213. https://doi.org/10.1287 /orsc.1100.0620.

De Clercq, D., Lim, D. S., \& Oh, C. H. (2013). Individual-level resources and new business activity: the contingent role of institutional context. Entrepreneurship Theory and Practice, 37(2), 303-330. https://doi.org/10.1111/j.15406520.2011.00470.x.

De Clercq, D., Lim, D. S., \& Oh, C. H. (2014). Hierarchy and conservatism in the contributions of resources to entrepreneurial activity. Small Business Economics, 42(3), 507-522. https://doi.org/10.1007/s11187-013-9515-7.

De Haan, J., \& Sturm, J. E. (2003). Does more democracy lead to greater economic freedom? New evidence for developing countries. European Journal of Political Economy, 19(3), 547-563. https://doi.org/10.1016/S0176-2680(03)00013-2.

De Ruysscher, C., Claes, C., Lee, T., Cui, F., Van Loon, J., De Maeyer, J., \& Schalock, R. (2017). A systems approach to social entrepreneurship. Voluntas: International Journal of Voluntary and Nonprofit Organizations, 28(6), 2530-2545. https://doi.org/10.1007/s11266-016-9704-5.

Djankov, S., La Porta, R., Lopez-de-Silanes, F., \& Shleifer, A. (2002). The regulation of entry. The Quarterly Journal of Economics, 117(1), 1-37. https://doi.org/10.1162 1003355302753399436.

Ebner, N. C., Freund, A. M., \& Baltes, P. B. (2006). Developmental changes in personal goal orientation from young to late adulthood: from striving for gains to maintenance and prevention of losses. Psychology and Aging, 21(4), 664-678. https://doi.org/10.1037/0882-7974.21.4.664.

Erikson, E. H. (1959). Identity and the life cycle: selected papers. Psychological Issues, 1, 1-171.

Erikson, E. H. (1994). Identity and the life cycle. New York: WW Norton \& Company.

Estrin, S., Korosteleva, J., \& Mickiewicz, T. (2013a). Which institutions encourage entrepreneurial growth aspirations? Journal of Business Venturing, 28(4), 564-580. https://doi. org/10.1016/j.jbusvent.2012.05.001.

Estrin, S., Mickiewicz, T., \& Stephan, U. (2013b). Entrepreneurship, social capital, and institutions: social and commercial entrepreneurship across nations. Entrepreneurship Theory and Practice, 37(3), 479-504. https://doi.org/10.1111/etap.12019.

Estrin, S., Mickiewicz, T., \& Stephan, U. (2016). Human capital in social and commercial entrepreneurship. Journal of Business Venturing, 31(4), 449-467. https://doi.org/10.1016/j. jbusvent.2016.05.003.

Funken, R., \& Gielnik, M. M. (2015). Entrepreneurship and aging. Encyclopedia of Geropsychology, 1-7. https://doi. org/10.1007/978-981-287-080-3_25-1.

Gielnik, M. M., Zacher, H., \& Frese, M. (2012). Focus on opportunities as a mediator of the relationship between business owners' age and venture growth. Journal of Business Venturing, 27(1), 127-142. https://doi.org/10.1016/j. jbusvent.2010.05.002.

Goltz, S., Buche, M. W., \& Pathak, S. (2015). Political empowerment, rule of law, and women's entry into entrepreneurship. Journal of Small Business Management, 53(3), 605-626. https://doi.org/10.1111/jsbm.12177.

Haans, R. F., Pieters, C., \& He, Z. L. (2016). Thinking about U: theorizing and testing $\mathrm{U}$-and inverted U-shaped relationships in strategy research. Strategic Management Journal, 37(7), 1177-1195. https://doi.org/10.1002/smj.2399.

Harper, D.A. (2003). Foundations of entrepreneurship and economic development. London: Routledge.

Hechavarría, D. M. (2016). The impact of culture on national prevalence rates of social and commercial entrepreneurship. International Entrepreneurship and Management Journal, 12(4), 1025-1052. https://doi.org/10.1007/s11365-015-0376-1.

Hechavarria, D.M., Ingram, A., Justo, R., \& Terjesen, S. (2012). Are women more likely to pursue social and environmental entrepreneurship? In K.D. Hughes \& J.E. Jennings (Eds.), Global women's entrepreneurship research: Diverse settings, questions and approaches (pp. 135-151). Cheltenham/ Northampton, U.K.: Edward Elgar.

Hechavarría, D. M., Terjesen, S. A., Ingram, A. E., Renko, M., Justo, R., \& Elam, A. (2017). Taking care of business: the impact of culture and gender on entrepreneurs' blended value creation goals. Small Business Economics, 48(1), 225-257. https://doi.org/10.1007/s11187-016-9747-4.

Heim, B. T. (2015). Understanding the decline in self-employment among individuals nearing retirement. Small Business Economics, 45(3), 561-580. https://doi.org/10.1007 /s11187-015-9660-2.

Heimonen, T. (2013). Entrepreneurship in golden years: creative opportunity or not? China-USA Business Review, 12(1), 52-66.

Hoogendoorn, B. (2016). The prevalence and determinants of social entrepreneurship at the macro level. Journal of Small 
Business Management, 54, 278-296. https://doi.org/10.1111 /jsbm.12301.

Hörisch, J., Kollat, J., \& Brieger, S. A. (2017). What influences environmental entrepreneurship? A multilevel analysis of the determinants of entrepreneurs' environmental orientation. Small Business Economics, 48(1), 47-69. https://doi. org/10.1007/s11187-016-9765-2.

Hörisch, J., Kollat, J., \& Brieger, S. A. (2019). Environmental orientation among nascent and established entrepreneurs: an empirical analysis of differences and their causes. International Journal of Entrepreneurial Venturing, 11(4), 373-893. https://doi.org/10.1504/IJEV.2019.101623.

House, F. (2014). Freedom in the world 2014: the annual survey of political rights and civil liberties. Lanham: Rowman \& Littlefield.

Howorth, C., Smith, S. M., \& Parkinson, C. (2012). Social learning and social entrepreneurship education. Academy of Management Learning \& Education, 11(3), 371-389. https://doi.org/10.5465/amle.2011.0022.

Hox, J. J. (2010). Multilevel analysis: techniques and applications (2nd ed.). New York: Routledge.

Inglehart, R. (1997). Modernization and postmodernization: cultural, economic, and political change in 43 societies. Princeton: Princeton University Press.

Inglehart, R., \& Welzel, C. (2005). Modernization, cultural change, and democracy: the human development sequence. New York: Cambridge University Press.

Kanfer, R., \& Ackerman, P. L. (2004). Aging, adult development, and work motivation. Academy of Management Review, 29(3), 440-458. https://doi.org/10.5465 /AMR.2004.13670969.

Katz, I. M., Rudolph, C. W., \& Zacher, H. (2019). Age and career commitment: meta-analytic tests of competing linear versus curvilinear relationships. Journal of Vocational Behavior, 112, 396-416. https://doi.org/10.1016/j.jvb.2019.03.001.

Kautonen, T., Tornikoski, E. T., \& Kibler, E. (2011). Entrepreneurial intentions in the third age: the impact of perceived age norms. Small Business Economics, 37(2), 219-234. https://doi.org/10.1007/s11187-009-9238-y.

Kautonen, T., Down, S., \& Minniti, M. (2014). Ageing and entrepreneurial preferences. Small Business Economics, 42(3), 579-594. https://doi.org/10.1007/s11187-013-9489-5.

Kautonen, T., Kibler, E., \& Minniti, M. (2017). Late-career entrepreneurship, income and quality of life. Journal of Business Venturing, 32(3), 318-333. https://doi.org/10.1016/j. jbusvent.2017.02.005.

Keohane, R. O. (1989). International institutions and state power: essays in international relations theory. Boulder: Westview Press.

Klapper, L., Laeven, L., \& Rajan, R. (2006). Entry regulation as a barrier to entrepreneurship. Journal of Financial Economics, 82(3), 591-629. https://doi.org/10.1016/j.jfineco.2005.09.006.

Kooij, D. T., de Lange, A. H., Jansen, P. G. W., Kanfer, R., \& Dikkers, J. S. E. (2011). Age and work-related motives: results of a meta-analysis. Journal of Organizational Behavior, 32(2), 197-225. https://doi.org/10.1002/job.665.

Lang, F. R., \& Carstensen, L. L. (2002). Time counts: future time perspective, goals, and social relationships. Psychology and Aging, 17(1), 125. https://doi.org/10.1037//0882-7974.17.1.125.

Lepoutre, J., Justo, R., Terjesen, S., \& Bosma, N. (2013). Designing a global standardized methodology for measuring social entrepreneurship activity: the global entrepreneurship monitor social entrepreneurship study. Small Business Economics, 40(3), 693-714. https://doi.org/10.1007 /s11187-011-9398-4.

Lévesque, M., \& Minniti, M. (2006). The effect of aging on entrepreneurial behavior. Journal of Business Venturing, 21(2), 177-194. https://doi.org/10.1016/j. jbusvent.2005.04.003.

Levinson, D. J. (1986). A conception of adult development. American Psychologist, 41(1), 3-13.

Lind, J. T., \& Mehlum, H. (2010). With or without U? The appropriate test for a U-shaped relationship. Oxford Bulletin of Economics and Statistics, 72(1), 109-118. https://doi. org/10.1111/j.1468-0084.2009.00569.x.

Linder, S., \& Foss, N. J. (2018). Microfoundations of organizational goals: a review and new directions for future research. International Journal of Management Reviews, 20(S1). https://doi.org/10.1111/ijmr.12154.

Lindenberger, U., \& Baltes, P. B. (1997). Intellectual functioning in old and very old age: Cross-sectional results from the Berlin Aging Study. Psychology and Aging, 12(3), 410-432.

Mackenzie, C. S., Karaoylas, E. C., \& Starzyk, K. B. (2018). Lifespan differences in a self-determination theory model of eudaimonia: a cross-sectional survey of younger, middleaged, and older adults. Journal of Happiness Studies, 19(8), 2465-2487. https://doi.org/10.1007/s10902-017-9932-4.

Mair, J., \& Marti, I. (2006). Social entrepreneurship research: a source of explanation, prediction, and delight. Journal of World Business, 41(1), 36-44. https://doi.org/10.1016/j. jwb.2005.09.002.

Mair, J., \& Marti, I. (2009). Entrepreneurship in and around institutional voids: a case study from Bangladesh. Journal of Business Venturing, 24(5), 419-435. https://doi. org/10.1016/j.jbusvent.2008.04.006.

McMullen, J. S., Bagby, D., \& Palich, L. E. (2008). Economic freedom and the motivation to engage in entrepreneurial action. Entrepreneurship Theory and Practice, 32(5), 875895. https://doi.org/10.1111/j.1540-6520.2008.00260.x.

Miller, T., Kim, A. B., \& Roberts, M. R. (2018). 2018 index of economic freedom. Washington, DC: Heritage Foundation.

Minola, T., Criaco, G., \& Cassia, L. (2014). Are youth really different new beliefs for old practices in entrepreneurship. International Journal of Entrepreneurship and Innovation Management 2, 18(2-3), 233-259. https://doi.org/10.1504 /IJEIM.2014.062881.

Minola, T., Criaco, G., \& Obschonka, M. (2016). Age, culture, and self-employment motivation. Small Business Economics, 46(2), 187-213. https://doi.org/10.1007/s11187-015-9685-6.

North, D. C. (1990). Institutions, institutional change, and economic performance. Cambridge: Cambridge University Press.

Nurmi, J. E. (1989). Development of orientation to the future during early adolescence: a four-year longitudinal study and two cross-sectional comparisons. International Journal of Psychology, 24(1-5), 195-214.

Nyström, K. (2008). The institutions of economic freedom and entrepreneurship: evidence from panel data. Public Choice, 136(3-4), 269-282. https://doi.org/10.1007/s11127-0089295-9.

Obschonka, M., \& Silbereisen, R. K. (2012). Entrepreneurship from a developmental science perspective. International 
Journal of Developmental Science, 6(3-4), 107-115. https://doi.org/10.3233/DEV-2012-12105.

Parker, S. C. (2009). The economics of entrepreneurship. Cambridge: Cambridge University Press.

Pathak, S., \& Muralidharan, E. (2016). Informal institutions and their comparative influences on social and commercial entrepreneurship: the role of in-group collectivism and interpersonal trust. Journal of Small Business Management, 54(S1), 168-188. https://doi.org/10.1111/jsbm.12289.

Pathak, S., \& Muralidharan, E. (2018). Economic inequality and social entrepreneurship. Business \& Society, 57(6), 11501190. https://doi.org/10.1177/0007650317696069.

Reynolds, P., Bosma, N., Autio, E., Hunt, S., De Bono, N., Servais, I., Lopez-Garcia, P. and Chin, N. (2005). Global entrepreneurship monitor: Data collection design and implementation 1998-2003. Small Business Economics, 24(3), 205-231.

Roberts, B. W., Walton, K. E., \& Viechtbauer, W. (2006). Patterns of mean-level change in personality traits across the life course: a meta-analysis of longitudinal studies. Psychological Bulletin, 132(1), 1-25. https://doi. org/10.1037/0033-2909.132.1.1.

Sahasranamam, S., \& Nandakumar, M. K. (2018). Individual capital and social entrepreneurship: role of formal institutions. Journal of Business Research Online first. https://doi. org/10.1016/j.jbusres.2018.09.005.

Salmela-Aro, K., \& Upadyaya, K. (2018). Role of demandsresources in work engagement and burnout in different career stages. Journal of Vocational Behavior, 108, 190-200. https://doi.org/10.1016/j.jvb.2018.08.002.

Sasabuchi, S. (1980). A test of a multivariate normal mean with composite hypotheses determined by linear inequalities. Biometrika, 67(2), 429-439. https://doi.org/10.1093 /biomet/67.2.429.

Schaie, K. W. (1965). A general model for the study of developmental problems. Psychological Bulletin, 64(2), 92-107. https://doi.org/10.1037/h0022371.

Schaie, K. W. (2016). Theoretical perspectives for the psychology of aging in a lifespan context. In K. W. Schaie \& S. L. Willis (Eds.), Handbook of the psychology of aging ( $8^{\text {th }}$ ed., pp. 110). San Diego: Elsevier Inc.

Schmidt, K. R. T., \& Teti, D. M. (2005). Issues in the use of longitudinal and cross-sectional designs. In D. Teti (Ed.), Handbook of research methods in developmental science (pp. 3-20). Malden, MA: Blackwell.

Sigman, R., \& Lindberg, S. I. (2019). Democracy for all: conceptualizing and measuring egalitarian democracy. Political Science Research and Methods, 7(3), 595-612. https://doi. org/10.1017/psrm.2018.6.

Singh, G., \& DeNoble, A. (2003). Early retirees as the next generation of entrepreneurs. Entrepreneurship Theory and Practice, 27(3), 207-226. https://doi.org/10.1111/15408520.t01-1-00001.

Snijders, T. A. B., \& Bosker, R. J. (2012). Multilevel analysis: an introduction to basic and advanced multilevel modeling (2nd ed.). Los Angeles, Calif.: Sage.

Srivastava, S., John, O. P., Gosling, S. D., \& Potter, J. (2003). Development of personality in early and middle adulthood: set like plaster or persistent change? Journal of Personality and Social Psychology, 84(5), 1041-1053. https://doi. org/10.1037/0022-3514.84.5.1041.
Stephan, U., Uhlaner, L. M., \& Stride, C. (2015). Institutions and social entrepreneurship: the role of institutional voids, institutional support, and institutional configurations. Journal of International Business Studies, 46(3), 308-331. https://doi. org/10.1057/jibs.2014.38.

Super, D. E. (1980). A life-span, life-space approach to career development. Journal of Vocational Behavior, 16(3), 282298. https://doi.org/10.1016/0001-8791(80)90056-1.

Terjesen, S. (2017). Social entrepreneurship among women and men in the United States. Small Business Administration and National Women's Business Council. Office of Advocacy, Small Business Administration: Special report

Terjesen, S., Lepoutre, J., Justo, R., \& Bosma, N. (2012). Global entrepreneurship monitor: 2009 report on social entrepreneurship. Wellesley, MA \& London: Babson College \& London Business School.

Terjesen, S., Bosma, N., \& Stam, E. (2016). Advancing public policy for high-growth, female, and social entrepreneurs. Public Administration Review, 76(2), 230-239. https://doi. org/10.1111/puar.12472.

Van Stel, A., Storey, D. J., \& Thurik, A. R. (2007). The effect of business regulations on nascent and young business entrepreneurship. Small Business Economics, 28(2-3), 171-186. https://doi.org/10.1007/s11187-006-9014-1.

Warr, P. (2008). Work values: some demographic and cultural correlates. Journal of Occupational and Organizational Psychology, 81(4), 751-775. https://doi.org/10.1348 /096317907X263638.

Welzel, C. (2013). Freedom rising. New York: Cambridge University Press.

Wennberg, K., Pathak, S., \& Autio, E. (2013). How culture moulds the effects of self-efficacy and fear of failure on entrepreneurship. Entrepreneurship \& Regional Development, 25(9-10), 756-780. https://doi.org/10.1080/08985626.2013.862975.

Whitbourne, S. K. (2019). Longitudinal, cross-sectional, and sequential designs in lifespan developmental psychology. In Oxford Research Encyclopedia of Psychology. Online first. https://doi.org/10.1093/acrefore/9780190236557.013.344.

Wiernik, B., Ones, D., \& Dilchert, S. (2013). Age and environmental sustainability: a meta-analysis. Journal of Managerial Psychology, 28(7/8), 826-856. https://doi.org/10.1108/JMP07-2013-0221.

Zacher, H., \& Frese, M. (2009). Remaining time and opportunities at work: relationships between age, work characteristics, and occupational future time perspective. Psychology and Aging, 24(2), 487-493. https://doi.org/10.1037/a0015425.

Zacher, H., Biemann, T., Gielnik, M. M., \& Frese, M. (2012). Patterns of entrepreneurial career development: an optimal matching analysis approach. International Journal of Developmental Science, 6(3-4), 177-187. https://doi. org/10.3233/DEV-2012-12111.

Zahra, S. A., \& Wright, M. (2011). Entrepreneurship's next act. Academy of Management Perspectives, 25(4), 67-83. https://doi.org/10.5465/amp.2010.0149.

Publisher's note Springer Nature remains neutral with regard to jurisdictional claims in published maps and institutional affiliations. 